\title{
Fekete Zsolt: A hajóraklevél változó szerepe a tengeri árufuvarozásban
}

Debreceni Jogi Mühely, 2013. évi (X. évfolyam) 2. szám (2013. április) 9-42.

\section{Bevezetés}

A hajóraklevélről az értékpapírjog tárgy keretében általában csak érintőlegesen esik szó. $\mathrm{Az}$ általam ismert hazai értékpapírjogi tankönyvekben a tipizálásnál és egy-két mondatos utalásnál hosszabban nem esik szó e dokumentumról. E dolgozattal tehát egy olyan reményeim szerint hiánypótló - tanulmány elkészítése volt a célom, amely bemutatja azt a szabályozási és gyakorlati alkalmazási környezetet, melyben a hajóraklevél intézménye müködik, másrészt több olyan szempontból is megvizsgálja e dokumentumot, amely alapján az elemezhető, harmadrészt pedig tekintettel van a hajóraklevél jövőjére, a most látható tendenciákra is. A dolgozatom szerkezeti felépítésében is igyekeztem ezt a rendszert követni.

A dolgozat készítésekor elsősorban angolszász országok szakirodalmát és jogszabályait vettem alapul. A nemzeti szabályozás mellett vizsgálatom másik alapjául a vonatkozó nemzetközi egyezményeknek a hajóraklevéllel összefüggésbe hozható lényegi rendelkezései szolgáltak. Annak érdekében, hogy az ezekböl leszürhető információk ne csak puszta, elméleti szabályok legyenek, igyekeztem a gyakorlat oldaláról is ellenőrizni azokat, illetve azt megvizsgálni, hogy az általános megállapítások hogyan érvényesülnek konkrét fuvarozóvállalatok gyakorlatában. Két, a tengeri fuvarozásban komoly szerepet betöltő vonalhajózási vállalat magyarországi képviselete volt segítségemre, a MAERSK HUNGARY Kft. ${ }^{1}$ és az MSC Magyarország Kft., ${ }^{2}$ akiknek a dolgozathoz nyújtott információkért és segítségért szeretnék ezúton is köszönetet mondani.

\section{A hajóraklevél környezete, történeti és szabályozási háttere}

\subsection{A tengeri fuvarozás rendszerének rövid áttekintése}

\subsubsection{A tengeri fuvarozás fajtái}

A tengeri fuvarozásnak hagyományosan két fő fajtáját különböztetik meg, a bérelt hajózást (charter) és a vonalhajózást (liner transportation).

A vonalhajózás ,a tengeri árufuvarozásnak az a fajtája, amikor a kereskedelmi hajók előre meghatározott kikötők között, meghirdetett menetrend szerint, meghatározott díjszabások és fuvarozási feltételek alapján tartanak fenn rendszeres szolgálatot" ${ }^{3}$ Ennél a tengeri fuvarozási típusnál az áru berakását követően - jellemzően, de nem minden esetben hajóraklevelet (bill of lading) állítanak ki, így dolgozatom szempontjából a vonalhajózásnak van elsődleges jelentősége.

A hajóraklevélnek történetileg kialakult három fö funkciója van: 1. az áru átvételének igazolása 2. bizonyíték a fuvarozási szerződésre 3. tulajdonjogot megtestesítő funkció (értékpapír-jelleg). A hajóraklevél kiállítása terén a feladónak fontos kezdeményező szerepe van, így - többek között - ha nem él a hajóraklevél igénylésének lehetöségével, akkor helyette olyan fuvarokmányt kap, ami nem átruházható. Ilyen például a tengeri fuvarlevél (sea waybill) vagy a kiszolgáltatási jegy (ship's delivery order).

A tengeri fuvarozás másik alaptípusa a bérelt hajózás. Akkor beszélünk bérelt hajózásról, ha a hajótulajdonos bérleti szerződés alapján (charterparty) az egész hajót bérbe adja egy hajóbérlőnek úgy, hogy a hajótulajdonos alapvetően fuvarozási szolgáltatást nyújt, és egy bizonyos szintig fenntartja magának a jogot a hajó irányítása és legénységgel, 
felszereléssel való ellátása tekintetében. ${ }^{4}$ A bérelt hajózás a tengeri fuvarozás kötetlenebb formája: nem fix kikötők között menetrend szerint közlekedö hajókról van szó, és a felek a mindenkori keresleti és kínálati viszonyok alapján, érdekeik szerint állapodnak meg. ${ }^{5} \mathrm{~A}$ bérelt hajózással kapcsolatban a dolgozat szempontjából fontos kiemelni azt, hogy bár a szerződő felek viszonyát alapvetően a bérleti szerződés szabályozza, ilyenkor is sor kerülhet hajóraklevél kiállítására.

A bérelt hajózásnál azért kulcsfontosságú a hajótulajdonos fentebb említett minimális szintü irányítási jogának fenntartása, mert a bérelt hajózást ez különbözteti meg a hajó(haszon)bérlettől, más néven csupasz hajótestbérléstől, ${ }^{6}$ mely esetben a felek viszonyát hajó(haszon)bérleti szerződés (bareboat vagy demise charterparty) vagy lízingszerződés (leasing) szabályozza. Ilyenkor a hajó tulajdonosa nem fuvarozási szolgáltatást nyújt a bérlőnek, hanem a hajót teljesen a rendelkezésére bocsátja, így a hajó nem a hajótulajdonos, hanem a bérlő birtokában és irányítása alatt van. A bérlő feladata gondoskodni legénységről, felszerelésről, az ő felelőssége a navigálás is. Abból kifolyólag, hogy - bizonyos tekintetben - hajótulajdonosként viselkedik, szerepe alapvetően más lesz, így amennyiben fuvarokmányt állítanak ki, egyértelmüen őt kell fuvarozónak tekinteni, és az alapján ő fogja viselni a felelősséget is. ${ }^{7}$ A cél rendszerint ez is, hiszen a gyakorlatban egy hajó (haszon)bérletére gyakran azok kötnek szerződést, akik maguk is fuvarozók, és szeretnék ideiglenesen növelni a fuvarozási kapacitásukat.

\subsubsection{A tengeri fuvarozás szereplői}

E helyütt szeretném áttekinteni a tengeri fuvarozás azon szereplöit, akik a téma szempontjából jelentős szerepet játszhatnak. E szereplőket érdekeik és tevékenységük alapján négy fó csoportba soroltam:

Fuvaroztatói (feladói) oldalon a legfontosabb szereplő a feladó (shipper) a fuvarozási szerződés egyik alanya, rendszerint egyúttal a fuvarozási szerződés előtt kötött, mögöttes adásvételi szerződés eladója.

Az áru kiszolgáltatására jogosultak (átvevők) egyike a címzett (consignee) lehet, akinek a nevét a hajóraklevélben kifejezetten feltüntették. Ha van mögöttes adásvételi szerződés, akkor a címzett annak vevője. Olyan esetekben, amikor a hajóraklevél átruházható, és erre sor kerül, az áru kiszolgáltatására a hajóraklevél-birtokos (holder) formálhat jogot, feltéve hogy a hajóraklevelet jogszerüen birtokolja. Ö lehet a címzett, de tőle eltérö személy is. Az értesítendő személy (notify party) az áru kiszolgáltatása során játszik fontos szerepet, nem véletlenül szolgál a hajórakleveleken külön rovat a megnevezésére. Személye befolyásolhatja azt is, hány eredeti hajóraklevél bemutatására van szükség (erről a bemutatás szabályai körében esik majd szó).

Fuvaroztatói oldalon a meghatározó szereplő a fuvarozó (carrier) a fuvarozási szerződés másik alanya. A fuvarozó fogalmára sokszor a hajótulajdonos (shipowner) kifejezést használják, ami vonalhajózás esetén a fuvarozóvállalatot, bérelt hajózás esetén a hajót bérbe adót jelöli. Az ő feladata a fuvarozás szerződésszerü teljesítése. A hajótulajdonos és a hajóskapitány (master) érdekeiket tekintve ugyanazon az oldalon állnak. A hajóskapitány számos helyzetben a hajótulajdonos képviselöje, a hajóraklevéllel kapcsolatban összefüggésbe hozható feladatai a hajóraklevél aláírása és az áru kiszolgáltatása. A hajóstiszt (mate) kiemelése annyiban indokolt, hogy az áru rakodásakor úgynevezett hajóstiszti elismervényt (mate's receipt) állít ki, aminek tartalma meghatározó lehet a hajóraklevélre nézve is.

A bérelt hajózás hajóbérlője (charterer) az egyetlen szereplő, aki - esettől függően feladói vagy átvevői is megjelenhet. Sőt, elméletileg nem kizárt a fuvarozói oldalon való megjelenés is (a fuvarozó adott esetben bérelt hajóval is elláthatja a fuvarozást), de csak 
zárójelesen, mivel ilyen esetben számára a hajóbérlés csak háttér- és nem fuvarozói fő́tevékenységként jelenik meg.

A feladót, a fuvarozót, és a kiszolgáltatásra jogosultat tekinthetjük alapvető szereplőknek.

Az egyéb szereplök csoportjába azokat soroltam, akik érdekük alapján az előző szereplők valamelyikéhez, vagy akár többhöz is kapcsolódhatnak. Ügynökkel bármelyik alapvető szereplő oldalán találkozhatunk (feladói megbízottként szállítmányozónak hívjuk), úgyszintén a rakodó (stevedore) esetében (értve ez alatt akár a fuvarozó saját alkalmazottait, akár egy rakodással foglalkozó cég szerződtetését). Az áru be- és kirakása során (ún. harmadik személyek által) okozott káráért való felelősséget alapvetően éppen az befolyásolja, hogy a rakodó az alapvető szereplők melyikének alkalmazásában vagy érdekében végezte munkáját. ${ }^{8}$ A hajóvizsgáló (surveyor) és az ellenőr (inspector) feladata egyaránt a szaktudás biztosítása az áru berakodása és az ezzel kapcsolatos adatok hajóraklevélben való rögzítése során, de míg az előző a fuvarozó, az utóbbi a fuvaroztató érdekének képviseletében jár el. ${ }^{9}$

A fenti klasszikus szerepeken kívül a Rotterdami Szabályzat új szerepeket is nevesít. ${ }^{10} \mathrm{~A}$ feladót például tehermentesítheti az, ha okirati feladót (documentary shipper) nevez meg. Ö egy, a feladótól eltérő olyan személy, akit a fuvarokmányokban feladóként tüntetnek fel, így a feladói jogokat és kötelezettségeket gyakorolja, illetve teljesíti. Ehhez hasonló a fuvarozó oldalán a teljesítő fél (performing party), aki bármely a fuvarozó körébe eső kötelezettséget teljesíthet. Ennek egy korlátozott szerepváltozata a tengerészeti teljesító fél (maritime performing party), aki csak az áruknak a feladási kikötőbe való érkezése és a rendeltetési kikötőből való elszállítása közötti időszakra eső fuvarozói kötelezettségeket teljesítheti. Az irányító fél (controlling party) fogalma ellenben nem teljesen új szereplőt takar: mindig azt a személyt kell ez alatt érteni, akinek az adott helyzetben joga van az áruval kapcsolatban utasítást, módosító rendelkezést adni (50-51. cikkek). Így ez a személy - esettől függően - lehet a feladó, az okirati feladó, a feladó által kijelölt más személy, a címzett, vagy a hajóraklevél-birtokos. ${ }^{11}$

\subsection{A hajóraklevél kialakulása, fejlődése}

A hajóraklevél és más értékpapírok kialakulásában és elterjedésében fontos szerepet játszott az európai kereskedelem növekedése, amely a XI-XII. században kezdödött. A hajóraklevél kialakulását egyes források a XIV. századra teszik, ${ }^{12}$ létezik azonban egy évszázaddal korábbi forrás is. ${ }^{13}$

A XVI. században széles körben elterjed a hajóraklevél Nyugat-Európában, erre utal, hogy ez idő tájt Itália és a Mediterrán Térség mellett francia és Hanza városokban is több forrás tesz említést ezen okmányról. ${ }^{14}$ Erre az időszakra teszik annak a napjainkban is élő hagyománynak a kialakulását, hogy a hajóraklevelet nem egyetlen példányban, hanem sorozatban állítják ki. Egyes feltételezések szerint ez azt a célt szolgálta, hogy egy eredeti példányt megőriz a feladó, egyet kap a fuvarozó, a többit pedig a címzettnek juttatnak el. ${ }^{15}$

A hajóraklevél funkciói közül elsőként az áruátvételi nyugta funkció fejlödött ki. A kereskedő mint feladó a kezdetekben együtt utazott a feladott áruval, azt a rendeltetési helyen eladta, melyet a fuvarozó e nyugta ellenében szolgáltatott ki neki vagy vevőjének. Amikor később a kereskedő már nem helyben adta el az árut, nem kellett utaznia, és a hajóraklevél tartalma kiegészült egy kiszolgáltatási rendelettel, hogy a fuvarozó tudja, kinek a részére kell teljesítenie. ${ }^{16}$ Ezt követte a fuvarozási szerződés rendelkezéseinek belefoglalása a dokumentumba, mellyel az utólagos viták felmerülését lehetett megelőzni, így a hajóraklevél a fuvarozási szerződés egyes rendelkezéseinek bizonyítékává is vált. Végül a szakirodalom ${ }^{17}$ a XVIII. századra teszi az átruházhatóság, a tulajdonjogot megtestesítő funkció kialakulását. Ebben szerepet játszott a fuvarozás hosszú ideje is: az 
ezalatt bekövetkezett körülményváltozások folytán érthetően merült fel az áru eladásának vagy biztosítékba adásának igénye.

A szerződési szabadság elvének elterjedésével a XIX. században megjelentek a hajóraklevélbe foglalt záradékok. ${ }^{18}$ Mivel e klauzulák is a szerződési feltételek közé tartoznak, tulajdonképpen ezek tették teljessé a hajóraklevél második funkcióját. ${ }^{19}$ Ezek jellemzően a fuvarozók érdekeit szolgálták, akik erősebb alkupozíciójuk alapján képesek voltak a fuvarozói felelősséget korlátozó vagy kizáró szövegek elfogadtatására a másik féllel. A helyzet szélsőséges esetekben odáig fajult, hogy a fuvarozók már a hanyagság miatti felelősség alól is megpróbáltak kibújni. Ez az árufeladók, bankárok és biztosítók együttes ellenállásához vezetett, melynek következtében egyes országokban különbözö megoldások születtek a probléma kezelésére. Sem a túl enyhe, sem a nagyon szigorú szabályozás nem tủnt megfelelő megoldásnak, a szabályozásbeli eltérés révén pedig egy újabb gátja alakult ki a tengeri fuvarozásnak. Ez vezetett ahhoz a felismeréshez, hogy a problémákat nemzetközi egyezmény útján lehet csak orvosolni. ${ }^{20}$

\subsection{A hajóraklevél szabályozási környezete}

A hajóraklevélre vonatkozó szabályozási rendszernek alapvetően két szintjét lehet megkülönböztetni: a nemzetközi egyezmények szintjét és az egyes országok nemzeti szabályozásának szintjét.

\subsubsection{A nemzetközi egyezmények}

Az előzőekben megfogalmazott problémákra a XX. század első negyedében egy nemzetközi egyezmény elfogadása látszott megoldásnak. Az egyezmény aláírását megelőzően egyeztetést folytattak az érintettek, a fuvarozók, az árufeladók, a bankárok és a biztosítók képviselői. Ennek eredménye a Nemzetközi Jogi Egyesület Tengerészeti Jogi Bizottsága által 1921-ben, Hágában összeállított tervezet lett. Ezt foglalták később nemzetközi egyezménybe és írták alá „1924. augusztus 25-én, Brüsszelben kelt nemzetközi egyezmény a hajóraklevelekre vonatkozó egyes jogszabályok egységesítése céljából" néven.

Az egyezmény elökészítői eleve nem kívántak átfogó kódexet alkotni a tengeri árufuvarozásra, elsőrendü céljuk a címben is deklarált szabályozásegységesítés, valamint az volt, hogy egy minimális szintủ védelmet biztosítsanak az árutulajdonosnak. Ennek érdekében meghatározták a fuvarozó alapvető kötelezettségeit és az általa élvezhető maximális védelmet, melyet a felelősség alól mentesítő és a felelősséget korlátozó klauzulák által élvezhet. A Hágai Szabályzat III. cikk 8. pontja értelmében az ettől való eltérés semmis, de a fuvarozó az V. cikk alapján vállalhat több kötelezettséget és nagyobb felelösséget.

A Hágai Szabályzatot sok ország ratifikálta, jelenleg több mint 70 azoknak a száma, amelyek ezt az eredeti egyezményt beépítették belső jogrendszerükbe. Továbbá nem kevés olyan ország is van, amelyik az egyezményhez ugyan nem csatlakozott, de önként a szabályzat tartalmának megfelelő nemzeti jogi szabályozást alkotott (pl. Bulgária, Brazília, Malajzia).

A széleskörü alkalmazás ellenére a Hágai Szabályzat nem hozott megelégedést hosszú távon. A vele kapcsolatos kritikák egy része azt kifogásolta, hogy a szabályzat elfogult a fuvarozókkal szemben. ${ }^{21}$ Egy másik része azt kifogásolta, hogy a szabályzat a tengeri fuvarozásnak csak egyes kérdéseit szabályozza, de nem szolgál átfogó kódexként. Harmadrészt az országok többsége csak az országból kimenő fuvarforgalomra vonatkozóan alkalmazta a szabályzatot, melynek alkalmazási köre így leszükültt. ${ }^{22}$ 
A megoldási javaslatok különböztek abban, milyen mértékü reformot képzeltek el a Hágai Szabályzatra vonatkozóan. Azok az országok, amelyek jelentős kereskedelmi flottával rendelkeztek, és amelyeknél ezáltal a fuvarozói érdekek voltak erősebbek, nem kívántak lényeges változtatást a szabályzaton. Az ezen az úton kidolgozott módosítási tervezeteket az úgynevezett Brüsszeli Jegyzőkönyvben foglalták össze, melynek szövegét 1968. február 23-án fogadták el és írták alá. Ezt nevezték Visby Módosításnak (a Hágai Szabályzat ezzel egységes szerkezetbe foglalt szövegét szokták Hágai/Visby Szabályzatnak nevezni). ${ }^{23}$

Míg a Visby Módosítást elsősorban nyugat-európai országok ratifikálták, addig azok a többségükben fejlődő - országok, amelyek vezető árutermelök voltak, és így a fuvaroztatói oldal érdekeit képviselték hangsúlyosabban, radikálisabb változtatásban gondolkodtak. ${ }^{24} \mathrm{E}$ törekvés nyomán egy olyan szabályzat tervezete készült el, amely már nem csak egyes kérdések harmonizációjára törekedett, hanem átfogó kódexként a tengeri árufuvarozási szerződés valamennyi aspektusára tekintettel kívánt lenni. Az egyezményt 1978. március 31-én írták alá Hamburgban, címe: „A tengeri árufuvarozásról szóló ENSZ egyezmény” (röviden Hamburgi Szabályzat). A szabályzat 1992. november 1-jén lépett hatályba.

A Hamburgi Szabályzat egyik legjelentősebb eltérése a Hágai és a Hágai/Visby Szabályzathoz képest, hogy a teljességre való törekvés igényével közelíti meg a tengeri árufuvarozást. A másik lényeges különbség, hogy mind a kimenő, mind a bejövő árufuvarozásra alkalmazandó. Harmadrészt fontos kiemelni, hogy míg a Hágai Szabályzat hajóraklevelet vagy más tulajdonjogot megtestesítő dokumentumot kívánt meg az alkalmazáshoz, addig a Hamburgi Szabályzat szélesíti ezt a kört, és más, tulajdonjogot nem megtestesítő dokumentum használata is lehetővé teszi a szabályzat alkalmazását. Mindezek ellenére azonban a Hamburgi Szabályzathoz csatlakozó országok részesedése a világ tengeri árufuvarozásában és kereskedelmi flottájában csupán töredéke a Hágai Szabályzat országainak, így a gyakorlatban továbbra is ez utóbbi bír meghatározó jelentőséggel.

E két szabályzat folytán mára meglehetősen komplex helyzet alakult ki. Vannak egyrészt azok az országok, amelyek csak a Hágai Szabályzatot (vagy azzal többnyire egyező szabályozást) építették be nemzeti jogukba. Van körülbelül 30 ország, amely ezen felül a Hágai/Visby Szabályzatot is ratifikálta. 20 körül van azoknak a száma, amelyeknél csak a Hágai/Visby Szabályzat alkalmazandó. A Hamburgi Szabályzatot körülbelül 30 ország ratifikálta. ${ }^{25}$ Vannak olyan országok is, mint Ausztrália, ${ }^{26}$ amelyek a Hágai/Visby Szabályzat és a Hamburgi Szabályzat rendelkezései alapján egyfajta vegyes rendszert fogadtak el. Így a gyakorlatban a fö gondot a más-más konvenciót, így eltérő jogelveket alkalmazó országok közötti tengeri fuvarozásból adódó jogviták jelentik. Mivel egy ilyen helyzet nem szolgálja megfelelően a tengeri árufuvarozás érdekét, várható volt, hogy előbb-utóbb lépés történik a változtatás érdekében. A megoldást ismét egy nemzetközi egyezmény keretében képzelték el. Az új egyezmény kidolgozásának ${ }^{27}$ kezdetei 2001-re nyúlnak vissza. Hosszas előkészítő munka után 2008 januárjában a Nemzetközi Tengerészeti Bizottság (Comité Maritime International) elfogadott egy előzetes szövegtervezet. A végleges szövegváltozatot az ENSZ Nemzetközi Kereskedelmi Jogi Bizottságának 41. ülésén fogadták el 2008 júliusában, New Yorkban. A konvenció hivatalos szövegét az ENSZ Közgyülés az év őszén fogadta el. Aláírásának megnyitására 2009. szeptember 23-án Rotterdamban került sor, így az egyezményt röviden Rotterdami Szabályzatnak nevezik. Az új egyezmény célja, hogy felváltsa a Hágai, a Hágai/Visby és a Hamburgi Szabályzatot, ezáltal egységesítse, kiterjessze és korszerüsítse a nemzetközi tengeri fuvarozásra vonatkozó szabályokat.

Az egyezményt eddig 24 ország írta alá, köztük különösen jelentős az Amerikai Egyesült Államok, Franciaország, Hollandia, Dánia, Svédország, Norvégia részvétele. Az 
egyezmény hatályba lépéshez 20 ország általi ratifikációra van szükség, ez idáig ezt csak két ország tette meg, Spanyolország és Togo.

A Rotterdami Szabályzat - a Hamburgihoz hasonlóan - szintén az átfogó szabályozás koncepciójából indul ki, terjedelmét tekintve is ez a legjelentősebb az eddigi egyezmények sorában. Alaposan és részletesen szabályozza a tengeri árufuvarozás kérdéseit, tekintettel van a modern igényekre is, így például az elektronikus fuvarokmányokra. Érdekessége, hogy kerüli a hajóraklevél kifejezést, ehelyett fuvarokmányokról, átruházhatókról és nem átruházhatókról ír, ami az elektronikus fuvarokmányokkal együtt a Hamburgi Szabályzatnál is tágabb alkalmazást kíván lehetővé tenni.

\subsubsection{A nemzeti szabályozások}

Bár a nemzeti szabályozási rendszerek értelemszerüen időben korábban léteztek, mint a nemzetközi konvenciók, ez utóbbiak jelentősen visszahatottak az előbbiekre. Így számos nemzeti jogszabály tanulmányozása során lehet azzal találkozni, hogy az nem tett mást, mint ratifikálta az adott nemzetközi konvenciót - teljesen vagy eltérésekkel, csak egy konvencióra vonatkozóan vagy több konvenció tekintetében is. Bizonyos nemzeti jogrendszerekben, különösen az angolszász országokban komoly szerepe van az esetjognak, azaz a bírói jogfejlesztésnek. Fontos jogelveket sokszor nem jogszabályok, hanem egyes jogesetekben megfogalmazott bírói értelmezések rögzítenek.

Az Egyesült Királyság esetében a nemzeti jogszabályok közül ugyanazon a néven két jogszabály is hatályban van. Mindkettő a tengeri árufuvarozásról szóló törvény (Carriage of Goods by Sea Act) nevet viseli, egyedül a címben szereplö évszám különbözteti meg őket. Az 1971-es törvény elvégzi a Hágai Szabályzat Visby módosításainak beemelését a nemzeti jogba ${ }^{28}$ (elötte az 1924-es, szintén ugyanilyen nevü törvény ${ }^{29}$ ratifikálta a Hágai Szabályzatot), tesz azonban ezzel kapcsolatos kiegészítéseket, ${ }^{30}$ illetve eltérö rendelkezéseket ${ }^{31}$ is. Az 1992-es törvény az 1855-ös hajóraklevél törvényt (Bill of Lading Act) helyezi hatályon kívül és határoz meg a fuvarokmányokra vonatkozóan definíciókat, abból eredő jogokat, kötelezettségeket és felelősséget.

Az Amerikai Egyesült Államok esetében korábban az egyes tagállamokban eltérö gyakorlat alakult ki valamennyi értékpapír szabályozása terén. Ebben egységességet 1952től kezdődően a Uniform Commercial Code (UCC) hozott, melynek 3. (forgatható értékpapírok) és 7. (tulajdonjogot megtestesítő dokumentumok) szakaszai több fontos általános és háttérszabályt tartalmaznak a hajóraklevélre vonatkozóan. Részletes szabályokat a hajóraklevélre (definíciók, átruházási szabályok, jogok, kötelezettségek, felelősség, zálogjog stb.) a szövetségi hajóraklevél törvény (Federal Bill of Lading Act) tartalmaz. A Hágai Szabályzatot az 1936-ban hatályba lépett tengeri árufuvarozásról szóló törvény ratifikálta bizonyos kiegészítésekkel. ${ }^{32}$ Az Amerikai Egyesült Államok nem csatlakozott a Hágai Szabályzat Visby módosításához. A Hamburgi Szabályzatot ugyan 1979-ben aláírta, azóta sem ratifikálta. Lehet, hogy erre a jövőben nem is lesz már szükség, minthogy az ország egyike a Rotterdami Szabályzat aláíróinak.

Kanada hajóraklevél törvénye (Bills of Lading Act) tömören szabályozza a hajóraklevéllel összefüggő kérdéseket (a címzett vagy forgatmányos jogai, egyes jogok fenntartása, a hajóraklevél bizonyíték funkciója). Kanadában jelenleg a Hágai/Visby Szabályzat van ratifikálva, erről a tengerészeti felelősségről szóló törvény (Marine Liability Act) 43. szakasza rendelkezik. Ugyanezen jogszabály azonban elöírja az illetékes miniszternek, hogy 2005. január 1-jét követően 5 évente vizsgálja felül a Hágai/Visby Szabályzat Hamburgi Szabályzattal való felváltásának kérdését, és ezzel kapcsolatos jelentését nyújtsa be a parlamentnek. 
Magyarország már tenger nélküli országként (land locked country) írta alá a Hágai Szabályzatot, melyet az1931. évi VI. törvénnyel ratifikált. A törvény „a hajóselismervényekre vonatkozólag az 1924. évi augusztus hó 25. napján Brüsszelben kelt egyezmény becikkelyezése tárgyában” címet viseli. A törvény 1 . §-a értelmében „A hajóselismervényekre vonatkozó egyes szabályok egységesitése végett az 1924. évi augusztus hó 25. napján Brüsszelben kelt nemzetközi Egyezmény és a hozzátartozó két aláíási jegyzökönyv az ország törvényei közé iktattatik”. A 2. § tartalmazza az egyezmény hivatalos magyar fordítását.

Érdekessége a törvénynek, hogy hajóraklevél fogalom helyett a hajóselismervény kifejezést használja, és a 2. § értelmében jogilag - legalábbis a Hágai Szabályzat tekintetében - ez számít hivatalos kifejezésnek a „bill of lading” fordítására, nem pedig a „hajóraklevél” szó. Másrészt az 1. cikk ${ }^{33}$ b) pontjában a fuvarozási szerződés fogalmi meghatározásánál a hajóraklevélhez hasonló tulajdonjogot megtestesítő okiratok magyar nyelvü fordításába hiba csúszott. Az angolszász „document of title” jogi kifejezést helytelenül nem tulajdonjogot vagy jogcímet megtestesítő okiratnak, hanem ,az áruknak tengeren való szállitására jogcímül szolgáló" okmánynak fordították. A téves fordítás egyúttal szövegbeli kiegészítéssel is járt az egyezmény eredeti szövegéhez képest. Mivel ugyanis a „document of title" kifejezést tévesen ,jogcímül szolgáló" okmánynak fordították, találni kellett valami szövegrészt, ami értelmesen megadja, mi az, aminek az okmány a jogcíméül szolgálhat. Így került bele a hivatalos magyar fordításba az egyezmény eredeti szövegében nem szereplő ,az áruknak tengeren való szállitására” szövegrész.

Magyarország 1979. április 23-án csatlakozott a Hamburgi Szabályzat aláíró országaihoz, azonban az egyezmény hazai kihirdetésére nem került sor.

A Rotterdami Szabályzathoz Magyarország eddig még nem csatlakozott aláíróként.

\subsubsection{A szabályozás egyéb forrásai}

A nemzeti jogrendszereken és a nemzetközi szabályozási eszközökön kívül vannak a szabályozásnak egyéb forrásai is, melyek irányadóak lehetnek az adott hajóraklevélre. Ilyen elsősorban maga a megkötött fuvarozási szerződés, melynek rendelkezései konkretizálják a feltételeket, illetve utalhatnak más források alkalmazására.

Egyéb források lehetnek továbbá azok a sztenderdizált kereskedelmi gyakorlatok, melyek jogilag ugyan nem kötelező erejüek, azonban gyakorlati jelentőségük nagy, illetve szerződésbe (fuvarokmányba) foglalva követendők lesznek. Kiemelendő itt a Nemzetközi Kereskedelmi Kamara (International Chamber of Commerce) által létrehozott INCOTERMS $^{34}$ és UCP Rules, ${ }^{35}$ vagy a Comité Maritime International (CMI) szabályzatai. ${ }^{36}$

Végül említést kell tenni a vonalhajózási társaságok felelősségbiztosítási rendszeréről, az úgynevezett P\&I biztosításról (protection and indemnity insurance). A biztosítás rendszere úgynevezett társaságokba (P\&I association, gyakori neve P\&I club) szerveződve épül fel, a fuvarozó a saját biztosítójától kap megtérítést olyan esetben, ha az általa fuvarozott áru veszteséget, sérülést szenved, vagy annak nem megfelelő kiszolgáltatása esetén, és emiatt vele szemben követelést érvényesítenek. E biztosítók szabályzatai (P\&I Rulebook) több olyan elöírást tartalmaznak, amelyek a hajóraklevél szempontjából is lényegesek. Különösen azok jelentősek, amelyek azt szabályozzák, mely esetekben nem részesülhet a fuvarozó védelemben. ${ }^{37}$ 


\section{A hajóraklevél}

Ebben a fejezetben a hajóraklevél egyes kérdéseit kívánom áttekinteni, annak kiállításától kezdve, az egyes funkciókon át, egészen annak bemutatásáig. Ennek során igyekszem minden egyes témakört több forrás alapján, a korábban ismertetett nemzetközi egyezmények, az egyes nemzeti jogrendszerbeli szabályozások és a megkérdezett fuvarozóvállalatoktól kapott, a gyakorlattal kapcsolatos tapasztalatok és információk alapján megvizsgálni.

\subsection{A hajóraklevél fogalma}

A hajóraklevél a tengeri fuvarozás egyik fuvarokmánya. Fuvarokmány azonban nem csak hajóraklevél lehet. Hajóraklevél kifejezés alatt az angolul „,bill of lading” (röviden: „B/L”), franciául „connaissement” és németül „Konnossement” névvel ellátott fuvarokmányokat értjük. Ennek a leggyakoribb fordítása a hajóraklevél, de ismert magyar nyelvü megfelelöi a hajóselismervény, a hajórakjegy és a rakodójegy kifejezések is.

A hajóraklevél fogalmát viszonylag kevés forrás határozza meg. A Hágai és a Hágai/Visby Szabályzat csupán a fuvarozási szerződés fogalmánál utal rá, melyből az szürhető le, hogy a hajóraklevél fuvarozási szerződést tanúsíthat és tulajdonjogot megtestesítő okirat. ${ }^{38} \mathrm{~A}$ konvenciók közül egyedül a Hamburgi Szabályzat (1. cikk 7. pont) definiálja kifejezetten a hajóraklevelet. Eszerint az ,olyan dokumentumot jelent, amely tanúsítja egy tengeri árufuvarozási szerzödés megkötését és az árunak a fuvarozó általi átvételét vagy berakását, amellyel a fuvarozó vállalja az áruk kiszolgáltatását e dokumentum bemutatása ellenében. Ilyen kötelezettségvállalásnak minösül a dokumentum olyan rendelkezése, mely szerint az árukat egy megnevezett személynek, valaki rendeletére vagy a bemutatónak kell kiszolgáltatni."

A Rotterdami Szabályzat átfogó jellegü megközelítése abban is megmutatkozik, hogy nem használja a hajóraklevél fogalmat, helyette általánosan fuvarokmányról (transportation document) beszél (1. cikk 14-20. pontok). Ennek fogalmánál két funkciót nevesít: a fuvarokmány egyrészt tanúsítja az árunak a fuvarozó vagy a teljesítő fél általi, a fuvarozási szerződés alapján történt átvételét, másrészt tanúsítja vagy tartalmazza magát a fuvarozási szerződést. A fuvarokmányok mindegyikében e kettőnél több elem nem is lehetne közös, mivel a harmadik funkcióval - a tulajdonjog megtestesítésének képességével - csak a hajóraklevél bírhat, ezáltal átruházható jelleggel is bírhat, míg más fuvarokmányok (tengeri fuvarlevél, kiszolgáltatási jegy) ${ }^{39}$ nem, csak az áru átvételének és a fuvarozási szerződésnek a tanúsítására képesek. ${ }^{40}$ (Ugyanakkor van a hajóraklevélnek olyan fajtája is, amely nem rendelkezik e képességgel.)

A vizsgált nemzeti jogszabályok közül egyedül az Egyesült Királyság 1992-es tengeri árufuvarozásról szóló törvényében találtam kifejezetten a hajóraklevélre vonatkozó meghatározást. A jogszabály inverz módon definiál, vagyis azt mondja meg, mi nem minősül hajóraklevélnek. Ez fogalom megköveteli az átruházhatóságot (típustól függően forgatással vagy egyszerü átadással), valamint deklarálja, hogy a fogalom az átvételt igazoló hajóraklevélre (received for shipment bill of lading) is vonatkozik. ${ }^{41}$

\subsection{A hajóraklevél funkciói}

\subsubsection{Az áru átvételének bizonyítása (receipt for goods shipped)}

A legkorábban az áru átvételét igazoló (átvételi elismervény) funkció alakult ki. Az áru puszta megnevezésén felül a feladó és a címzett számára fontos volt annak tanúsítása is, 
hogy milyen mennyiségü és állapotú áru feladására került sor. Minél kevesebb vagy kevésbé részletes azonban az áruról feltüntetett információ, a fuvarozó számára annál kisebb a veszélye annak, hogy áruhiány vagy sérülés miatt felelősségre vonják, így elterjedtté vált az olyan klauzulák alkalmazása a hajóraklevélben, melyek csökkentették a fuvarozó felelősségét. A fuvarozónak nem is állhat rendelkezésére minden típusú áruféleség tulajdonságainak pontos megállapítására alkalmas eszköz, nem beszélve a csomagolt vagy konténerben szállított árukról. Az érdekellentétből adódó probléma megoldása érdekében a nemzetközi egyezmények szabályozták egyrészt, hogy a hajóraklevelet mikor kötelező kiállítani, és hogy annak mit kell tartalmaznia. ${ }^{42}$ Másrészt a feladót tették felelőssé azért, hogy az általa megadott adatok hitelesek legyenek. ${ }^{43}$ Harmadrészt a fuvarozónak lehetővé tették, hogy mentesüljön az árutulajdonságok feltüntetésének kötelezettsége alól olyan esetekben, amikor azok valódisága megkérdőjelezhető, vagy nincsen megfelelő eszköze azok hitelesítésére, ${ }^{44}$ más esetekben azonban a felelősségkorlátozási célú klauzulák semmisek. ${ }^{45}$

A hajóraklevélnek az áru átvételét igazoló funkciója kapcsán szólni kell annak bizonyító erejéről. A konvenciók itt követik azt az angolszász rendszerekben létező elvet, mely szerint a hajóraklevél tartalma a feladó számára úgynevezett ,prima facie evidence”, vagyis megdönthetö vélelem. ${ }^{46}$ Azaz, hacsak a fuvarozó nem bizonyítja az ellenkezőjét, a hajóraklevélben foglaltakat valósnak kell tekinteni. Ugyanez a feladótól eltérő, jóhiszemü harmadik személyek - azaz a címzett vagy más hajóraklevél-birtokos - kezében már ennél komolyabb bizonyító erővel rendelkezik: úgynevezett ,conclusive evidence”, azaz megdönthetetlen vélelem a fuvarozóval szemben. ${ }^{47} \mathrm{~A}$ harmadik személyek fokozottabb védelme azért indokolt, mert ők nem vettek részt az áru feladásának folyamatában, a hajóraklevél megszerzésekor csak az abban foglalt információkban bízhattak. E szabályok a nemzeti jogrendszerekben már többé-kevésbé ugyanezen elvek mentén korábban is léteztek, azonban egyes országokban, mint például az Egyesült Királyság, a jóhiszemüség mellé a visszterhes szerzés is társul követelményként. ${ }^{48}$

\subsubsection{Bizonyíték a fuvarozási szerződésre (evidence of the contract of carriage)}

A hajóraklevél második fontos feladata a fuvarozási szerződéssel kapcsolatos bizonyító funkció. Nagyon fontos hangsúlyozni, hogy a hajóraklevél kiállítását mindig megelőzi a fuvarozási szerződés megkötése. Ez a gyakorlatban az ügyféllel történő egyeztetés eredményeképpen, a fuvarozóvállalat által közzétett általános szerződési feltételek alapján történik. A fuvarozási szerződés megkötése szóban, vagy üzenetváltással is történhet. Ott, ahol nem kerül sor a fuvarozási szerződés írásbeli rögzítésére, megnő a hajóraklevél fuvarozási szerződés meglétét bizonyító szerepe.

Nagyon lényeges, hogy a hajóraklevél nem maga a fuvarozási szerződés, nem a fuvarozási szerződés írásba foglalt formája ${ }^{49}$ és nem is része annak. ${ }^{50}$ Bár annak kiállításában - a szükséges adatok megadásával - a feladó is közremüködik, a kiállítás nem szerződés módjára kétoldalúan, hanem egyoldalúan, a fuvarozó (korábban a hajóskapitány, ma már jellemzően az ügynök) aláírásával történik. Az mondható tehát, hogy a hajóraklevél tartalmazza a fuvarozási szerződés egyes feltételeit, és igazolja, hogy sor került annak megkötésére. ${ }^{51}$ A hajóraklevélnek ezen - szerződési feltételeket igazoló - hatása az áru átvételét igazoló funkcióhoz hasonlóan megdönthető vélelem lesz a feladó számára, és megdönthetetlen vélelem jóhiszemű harmadik személyek számára. ${ }^{52}$

Mielőtt rátérnék a harmadik funkcióra, szeretném kiemelni, hogy a magyar polgári törvénykönyv a fuvarozási szerződésről szóló részben, bár nem szabályozza magát a hajóraklevelet, de a fuvarlevek mindegyikére vonatkozóan, általánosan kimondja azt, hogy a fuvarlevél rendelkezik az e fejezetrészben elsőként és másodikként bemutatott bizonyító 
funkciókkal: „Ha a szerzödö felek a fuvarozásról fuvarlevelet állitanak ki, a fuvarlevél bizonyítja a fuvarozási szerzödés létrejöttét, illetöleg a küldemény átvételét. Az átvétel napja - míg mást nem bizonyítanak - az a nap, amelyen a fuvarlevelet a fuvarozó aláirta (lebélyegezte)". 53

\subsubsection{Tulajdonjog megtestesítése (document of title)}

A tulajdonjog megtestesítésének funkciója azt jelenti, hogy a hajóraklevél a benne foglalt, áru feletti jogot megtestesíti, annak mintegy megfogható szimbólumaként lehetővé teszi az áru fizikai birtoklása nélkül is az azzal való rendelkezést. Az e funkcióval bíró hajóraklevél nem csak tulajdonjogot testesít meg, hanem mindazokat az egyéb jogokat is, melyek ebből fakadnak: az út során az áruval kapcsolatos utasításadási jogot, megérkezéskor az áru kiszolgáltatásának követelését, az áru átruházásának és hitelfelvétel céljából való megterhelésének lehetőségét, valamint jogsértés esetén perlési jogot. Hozzá kell azonban tenni, hogy ebben a kérdésben az egyes országok szabályozása eltérő lehet. Az értékpapírok tipizálásánál a hazai szakirodalom egységesnek látszik abban, hogy a hajóraklevél - a közraktári jegyhez hasonlóan - a dologi jogi értékpapírok csoportjába tartozik, azaz a benne feltüntetett áru feletti tulajdonjogot testesíti meg. Az angolszász szabályozási rendszerekben ennek megfelelője a „document of title” kifejezés. ${ }^{54}$ Van azonban olyan értelmezés is, hogy a hajóraklevél a benne leírt árunak nem a tulajdonjogát, hanem csupán a birtokláshoz való jogot - beleértve az áru átvételére való jogosultságot, ${ }^{55}$ illetve az áruátvétel meghatározásának lehetőségét ${ }^{56}$ - testesíti meg, így átruházni is csak az áru birtokát lehet, de a teljes tulajdonjogot nem. Az egyszerübb szóhasználat érdekében azonban a továbbiakban a tulajdonjog kifejezést fogom használni.

A hajóraklevél e funkciójának kialakulása két fő célt szolgált. Az egyik az áru eladásának lehetősége a fuvarozás ideje alatt. Bár az árufeladásra - és emiatt a hajóraklevél kiállítására is - egy korábban megkötött adásvételi szerződés alapján került sor, a címzett (az ügylet eredeti vevője) dönthetett úgy, hogy a még kézhez sem vett árut a hajóraklevél átruházásával értékesíti. A másik cél a hitelhez jutás lehetőségének biztosítása. Egy bank számára hitelfedezetként csak olyan hajóraklevél lehet elfogadható, amely lehetővé teszi számára adósa nem (szerződésszerü) teljesítése esetén, hogy a hajóraklevéllel fedezett áruból követelését kielégíthesse.

E célok teljesülése csak akkor lehetséges, ha a hajóraklevél tulajdonjogot testesít meg, melyhez szorosan kapcsolódik az átruházható minőséggel való rendelkezés is. Ugyanakkor nem minden hajóraklevél átruházható, ilyenek a névre szóló hajóraklevelek, amellyel fedezett árut kizárólag az abban feltüntetett címzettnek lehet kiszolgáltatni. Ezzel kapcsolatban két fontos kérdés merül fel. Az egyik, hogy a nem átruházható hajóraklevél rendelkezik-e értékpapír-funkcióval, a másik, hogy az ilyen hajóraklevelet mi különbözteti meg a szintén nem átruházható, egyértelmüen nem értékpapír-jellegü tengeri fuvarlevéltől. Az első kérdésre az angol szakirodalom ${ }^{57}$ azt az álláspontot képviseli, hogy a névre szóló hajóraklevél nem értékpapír, mivel az 1992-es tengeri árufuvarozási törvény a hajóraklevéltől fogalmilag megköveteli az átruházhatóságot, így az ilyen dokumentum a tengeri fuvarlevél szintjére sorolandó. ${ }^{58}$ Magyar értékpapírjogi szemmel nézve ezzel ellentétes álláspontot tartok helyesnek, azt gondolom, hogy az átruházhatóság önmagában nem befolyásolja az adott dokumentum értékpapír-jellegét, bár az igaz, hogy az átruházhatóság hiánya egy lényeges tulajdonságától fosztja meg a papírt.

A második kérdéssel több helyen is találkoztam vizsgálataim során. A két dokumentum egyrészt formailag is különbözik, mivel a nem átruházható hajóraklevél formanyomtatványa többnyire ugyanolyan, mint az átruházható változaté, a különbség annyi, hogy az előlapon fel van tüntetve az át nem ruházható minőség. A másik különbség, 
hogy a nem átruházható hajóraklevél esetén az áru kiszolgáltatására csak annak bemutatása ellenében kerülhet sor, tehát azt el kell juttatni a címzetthez, különben az nem fogja tudni az árut kiváltani. A tengeri fuvarlevél esetén azonban ez hiányzik.

Sok fuvarozó gondolja úgy, hogy ezt a harmadik funkciót ma már meghaladta a kor, és a hajóraklevélnek e szerepét el kellene különíteni a többi funkciótól, hogy a fuvarozót ne terheljék az átruházásokból adódó problémák és viták, mivel e kérdés nem az ő érdekkörébe tartozik, illetve az átruházásokra neki nincsen befolyása. ${ }^{59} \mathrm{E}$ gondolat megjelenik a Rotterdami Szabályzatban is, melyre a következő fejezetrészben külön ki fogok térni.

A hajóraklevélnek a Rotterdami Szabályzatban (51. cikk) megjelenő, újnak tekinthető funkciója, hogy a hajóraklevél birtoklása meghatározza a mindenkori irányítási jogot gyakorló fél (controlling party) személyét.

\subsection{A hajóraklevél kiállítása}

A hajóraklevél kiállítása a nemzeti jog alapján nem feltétlenül kötelező. A Hágai és a Hágai/Visby Szabályzat (III. cikk 3. pont), valamint a Hamburgi Szabályzat (14. cikk 1. pont) értelmében szintén nem kötelező kiállítani, csakis akkor, ha azt a feladó kéri. A Rotterdami Szabályzat (35. cikk) a feladót, valamint az ő hozzájárulásával az okirati feladót jogosítja fel arra, hogy átruházható vagy nem átruházható fuvarokmányt, illetve annak elektronikus formáját kérje kiállítani a fuvarozótól. A Rotterdami Szabályzat azonban kivételt is lehetővé tesz: nem köteles a fuvarozó átruházható hajóraklevelet kiállítani, ha a feladóval korábban úgy állapodtak meg, hogy nem alkalmaznak ilyen típusú fuvarokmányt, valamint akkor sem, ha kereskedelmi szokás, szokvány vagy gyakorlat szerint ilyet nem alkalmaznak. Itt érhető tetten a hajóraklevél átruházhatósággal összefüggő funkciójának visszaszorulására irányuló fuvarozói érdek érvényesülése.

\subsubsection{A hajóraklevél kiállításának lépései}

A hajóraklevél-kiállítás menetének ismertetésénél igyekszem a folyamatot úgy bemutatni, hogy az tükrözze a megkérdezett fuvarozóvállalatok mai gyakorlatát is.

A gyakorlatban az első lépést a feladó (vagy ügynöke) teszi meg azáltal, hogy árajánlatot kér a fuvarozóvállalattól. Ha úgy dönt, hogy a kapott árajánlat megfelelö, akkor sor kerül a befoglalásra (hajótérkönyvelés). A fuvarozó visszaigazolása arra vonatkozóan, hogy elvállalja a fuvar teljesítését, azért nagyon lényeges, mert ez lesz az az időpont, amikor létrejön a fuvarozási szerződés (a felek egybehangzó akaratnyilatkozat-nyilvánítására kerül sor).

Ezt követően a fuvarozó egyezteti a feladóval az áru átadásának, rakodásának kérdéseit. Miután a feladó átadja az árut a fuvarozónak, erről alapesetben átvételi elismervényt (receipt) kell kiállítani, feltüntetve abban az áru alapvető adatait (fajtáját, mennyiségét, állapotát) ${ }^{60}$ sokszor a későbbi tengeri szakaszra vonatkozó részleteket is (melyik kikötőből hová fogják fuvarozni). Kombinált fuvarozás esetén viszont nem feltétlenül átvételi elismervényt alkalmaznak. Ilyen esetben ugyanis a tengeri fuvarozási szakaszt megelözi a szárazföldi szakasz (előfutás), így átvételi elismervény helyett az adott szárazföldi fuvarozási ágnak megfelelő fuvarlevelet (CMR vagy vasúti fuvarlevél) állítanak ki, ami egy átvételi elismervénynél annyiban több is, hogy követhetővé teszi az áru útját, a kezelésért felelős személyét. Feladói igény alapján elméletileg volna lehetőség átvételt igazoló hajóraklevél kiállítására is, de ez ritka (ennek okait később fejtem ki).

Az átvételtől kezdődően már fuvarozói irányítás és felelősség alatt áll az áru. Hajóraklevél kiállításának kezdeményezésére rendszerint csak ezt követően kerül sor, hiszen csak a 
fuvarozónak történő átadással lesz végleges, milyen árut adott fel a feladó. Bizonyos esetekben azonban ezt megelözően, akár még hajótérkönyvelés előtt szükség lehet a hajóraklevéllel kapcsolatos egyeztetésre (pl. milyen feltételeket támaszt a bank, föleg ha közben valamilyen speciális klauzula feltüntetése lenne szükséges a hajóraklevélen). A kiállítást követően már sokkal nehezebb és emiatt időigényesebb a feltételekhez igazodni, a szükséges változtatásokat végrehajtani, nem beszélve az időközben felmerült kiállási, rakodási költségekröl.

A hajóraklevél elökészítésében a feladónak általában fontos szerepe van azáltal, hogy ö tölti ki azt a formanyomtatványt, amellyel megadja a fuvarozáshoz szükséges adatokat, amelyek a kiállítandó hajóraklevél tartalmi elemeit fogják képezni. A gyakorlatban ez úgynevezett feladási előírás (shipping instructions) ügyfél általi megadásával történik, gyakran a vállalat honlapján keresztül.

Ezeket az adatokat a fuvarozó minden esetben alaposan ellenőrzi. Az árura vonatkozó információk egyezőségének vizsgálata elsősorban az árut kísérő exportokmány adatainak vizsgálatát jelenti. Az összehasonlítás alapja továbbá az átvételi elismervény(ek)ben, az árujegyzéken, a berakodás után hajóstiszti elismervényben ${ }^{61}$ szereplő adatok és benne feltüntetett esetleges megjegyzések. Az adatok vizsgálata az azok valódiságáért való fuvarozói felelősség miatt lényeges, ezért ennek során a felek elméletileg többféle eszközt bevethetnek a vitatott kérdések, föleg a mennyiség és az állapot tisztázása érdekében, ${ }^{62}$ azonban a gyakorlatban a hajóraklevélen széles körben alkalmazott, feladó általi egyoldalú meghatározást deklaráló klauzulák alkalmazásával ezek jelentősége ma már csekély. Ha azonban e kérdésekben végül a feleknek nem sikerülne megegyezniük, az a hajóraklevél kiállításának visszautasításával járhat. ${ }^{63}$

Miután a fuvarozóvállalat rendszerébe ezek az ellenőrzött adatok bekerülnek, az ügyfél rendszerint kap egy elektronikus hajóraklevél-tervezetet (,verified copy”), amelyen ellenőrizheti az adatokat, mielőtt még a végleges hajóraklevél kiállítására sor kerülne.

Míg a hajóraklevél előkészítésében a feladónak van fontos szerepe, annak aláírása - a fuvarozó nevében - egyoldalúan a fuvarozó képviselője által történik, maga a feladó nem írja alá azt. Az aláírás komoly felelősség, ezért arra eredetileg kizárólag a hajóskapitány volt jogosult, helyette más személy csak a hajóskapitány vagy a hajótulajdonos által aláírt felhatalmazó levél (letter of authority) alapján tehette ezt meg. ${ }^{64}$ A mai világban a konténerizáció időszakában ilyen mennyiség mellett azonban képtelenség lenne mindent a hajóskapitánynak aláírni, helyette a fuvarozó ügynöke (a fuvarozóvállalat adott országbeli leányvállalata) teszi ezt meg.

A hajóraklevél kiállítására elvileg a berakást követő ésszerü időn belül kell, hogy sor kerüljön, így tehát a feladó részére, ha ezt kifejezetten kéri, ki kellene állítani a hajóraklevelet (átvételt igazoló hajóraklevél), nem kötelezhető arra, hogy várja meg, míg a többi árut is berakják. ${ }^{65}$ A gyakorlatban azonban ez jellemzően nem így érvényesül, részben az átvételt igazoló hajóraklevél iránti csekély feladói igény, részben a fuvarozóvállalatok szabályozása miatt. A hajóraklevél tényleges kiállítására sok esetben nem az átvételt, nem is a hajóba rakást, hanem csak az elhajózást követően kerül sor. Az elhajózáskor történő kiállítás szolgálhatja azt, hogy a becsült fuvarozási időt így lehet a legpontosabban meghatározni, ott azonban, ahol a fuvarozó nem vállal felelősséget a tranzitidőért, ez nem annyira érdekes. Sokan azért is csak elhajózáskor állítják ki e dokumentumot, mert ez így sztenderdizálható folyamat, és nem kell külön szabályt alkalmazniuk a csak tengeri és a kombinált fuvarozási hajóraklevél esetében. A feladó számára ez egyedül amiatt lehet kényelmetlen, hogy a berakás ugyan már megtörtént, de esetleg még napokat kell várni a hajóraklevél kiállítására, és addig nem tudja elindítani az akkreditív iránti eljárást a banknál. 
A kiállítás időpontjának ilyen módon való fuvarozóvállalati szabályozása is a hajóraklevél ügynök általi aláírása felé tolja a rendszert: a hajóskapitány nem tudná az elhajózást követően (azaz már a tengeren) elvégezni ezt a feladatot, ráadásul egyszerre valamennyi árura. Ezt az aláírási aktust a fuvarozó ügynöke is jellemzően elektronikusan, az informatikai rendszer által nyomtatáskor generált elektronikus aláíás formájában teszi meg.

A kiállított hajóraklevelet ezután a fuvarozó eljuttatja a feladónak. A biztonsági szempontok érdekében ez személyes átadással vagy futár útján történik, és az átvétel kellően dokumentált (átvevő, keltezés, aláírás).

Jogosulatlanul kiállított hajóraklevélről beszélünk, ha az annak kiállítására vonatkozó szabályokat megsértették, különösen, ha annak aláírására felhatalmazás nélkül került sor. Ha ez történne, az nem feltétlenül tenné értéktelenné a hajóraklevelet, annak jóhiszemü szerzője akár követelhetné is a teljesítést - elmaradás esetén pedig a kárát - a fuvarozótól, aki viszont legfeljebb csak az általa emiatt szenvedett kárának megtérítését követelhetné a jogosulatlan kiállítóval szemben. ${ }^{66}$

\subsubsection{A sorozatban kiállított hajóraklevél}

A hajóraklevelet nagyon gyakran nem egy, hanem több eredeti példányban, azaz sorozatban állítják ki, ${ }^{67}$ bár vannak országok, ahol nem megengedett a sorozatban történő kiállítás. ${ }^{68}$ A sorozat leggyakrabban három példányból áll - gyakorlatban használt nevén három harmad $(3 / 3)$-, de létezhet akár hat ${ }^{69}$ vagy nyolc példányból álló teljes sorozat (fullset) is. Ebben általában a feladó kérése a döntő. Az eredeti példányok mellett jellemzö, hogy ügyféli kérésre aláírás nélküli másolatot (copy) is kiállítanak, van, ahol ugyanannyi példányban, mint amennyi az eredetik száma.

A fuvarozóvállalatoknál nem jellemző, hogy maradna eredeti példány. Ez iránt manapság azért sincs akkora igény, mert a fuvarozói iroda informatikai rendszere megfelelöen tartalmazza a kiállított hajóraklevelet. Többnyire csak a bevonást követően kerül vissza a hajóraklevél a vállalathoz, amelyet ezt követően még több évig megőriznek.

Sorozat esetén a sorozat minden példánya eredetinek minősül, és az általános szabály szerint az áru kiszolgáltatásához elegendő egyetlen eredeti példány bemutatása is, aminek következtében a többi példány érvényét veszíti ${ }^{70}$ (kivételekről a bemutatás problémái körében fogok szót ejteni).

\subsubsection{A hajóraklevél javítása, cseréje}

Előfordulhat, hogy a kiállítást követően derül ki, hogy a hajóraklevélben téves információt tüntettek fel. Ennek megoldása a hajóraklevél javítása vagy cseréje. Erre harmadik felek védelme érdekében csak akkor kerülhet sor, ha a hajóraklevél valamennyi eredeti példánya még a feladónál van. Sorozatban kiállított hajóraklevelek esetében ez azt jelenti, hogy míg az áru kiszolgáltatásához rendszerint elegendő egyetlen eredeti példány bemutatása, addig javításra vagy kicserélésre csakis valamennyi korábban kiállított eredeti példány visszaszolgáltatása mellett kerülhet sor. E kettö összefügg: csere esetén éppen azért kell valamennyi korábbit bevonni, mert ha akár egyetlen cseréletlen példány is marad, a kiszolgáltatásra annak alapján is sor kerülhetne.

A fuvarozó által végzendő csere történhet valamennyi korábbi példány bevonása mellett új példányok (switch bill) kiállításával, vagy a módosításnak valamennyi eredeti példányra történő rávezetésével és aláírásával. Ismert ${ }^{71}$ egy olyan megoldás is, amikor nincs szükség a hajóraklevél példányainak visszaszolgáltatására, és a fuvarozó a feladónak csak helyesbítést tartalmazó értesítést (notice) küld, ami arra kötelezi a feladót, hogy 
hasonlóképpen tájékoztasson mindenkit a változásról, akinek a hajóraklevelet átadja, akire azt átruházza, vagy akinél azt letétbe helyezi.

Minden olyan esetben, amikor nem történik meg a hibásan kiállított példányok bevonása, az azzal a kockázattal jár, hogy két, eltérő tartalmú hajóraklevél-sorozat lesz forgalomban. Egy ilyen helyzet számos további problémát (felelősség, a módosítás köre, a nemzetközi konvenciók alkalmazhatósága) ${ }^{72}$ eredményezne. Az általam kérdezett fuvarozóvállalatok kizárólag az eredeti sorozat bevonását tartják megfelelő megoldásnak.

\subsection{A hajóraklevél formai kellékei}

A hajóraklevél a fogalmából és funkcióiból adódóan kizárólag írásbeli formában lehetséges, hiszen a legrégebbi funkciója éppen az, hogy a feladott áru átvételének elismervényeként szolgáljon, de értékpapírkénti felhasználása is okirati formát követel meg. Mivel maga a fuvarozási szerződés nem feltétlenül írásban jön létre, a fuvarlevél - a másodikként bemutatott funkciója folytán - pótolja az abban szereplö lényegi feltételek írásban történő rögzítését, egyúttal bizonyítja, hogy fuvarozási szerződés megkötésére került sor. Különösen a bemutatáskor jelentős a hajóraklevél eredetisége, ami nem engedi meg a másolat vagy a faxon küldött változat felhasználását.

Megkülönböztetendő a hajóraklevél előlapja (face) és hátlapja (back). A gyakorlatban széles körben az terjedt el, hogy az elölap az a rész, amely rovatokat és kitöltendő helyeket tartalmaz, ahová a konkrét fuvarozással kapcsolatos adatok írandók (a feladó, a címzett és az értesítendő fél személye, a berakási és a rendeltetési kikötő, az áru és annak leírása, a fuvardíj és egyéb költségek stb.), míg a hátlap a fuvarozási szerződés feltételeit rögzíti, előre nyomtatottan és számozottan. Egyes fuvarozók szerint azonban éppen fordítva igaz: az előlap tartalmazza a szerződési feltételeket, és a hátlapra kell írni az adatokat. Az AtlanticContainer Line honlapján ${ }^{73}$ például ilyen hajóraklevelet találunk.

A gyakorlatban hajóraklevél formai követelményeit illetően általánosan jellemző a fokozott biztonságra törekvés. Az eredetiség garanciái közé tartozik a hajóraklevél egyedi sorszámozása, továbbá az, hogy az elölap és a hátlap alap egyazon lapon található, a rontott példányok kezelésére/bevonására vonatkozó szigorú szabályok, továbbá a vízjel és a szabad szemmel nem látható elemek.

Ha a feladni kívánt árura vonatkozó információk nem férnek el a szokásos hajóraklevélnyomtatványon, akkor a további adatokat valamilyen kiegészítő lapra (,riderpage”) lehet felvezetni, mely ilyenkor is ugyanazt a sorszámot tartalmazza, és ennek hátlapján is ugyanazok a szerződési feltételek szerepelnek elválaszthatatlanul, mint amik a szokásos hajóraklevél hátlapján is. Mindezek a hajóraklevél kiállítását meglehetősen költségessé teszik, ugyanakkor körültekintő eljárás esetén garantálják a biztonságot.

A forgatható hajóraklevelek forgatmánya a dokumentum hátoldalán van, még akkor is, ha a hátlap nem üres, hiszen az szokta tartalmazni a szerződési feltételeket. (Az Atlantic Container Line hajóraklevele a szerződési feltételek mellett üres helyet szorít a forgatmányok számára.) Ezzel kapcsolatban fontos megjegyezni, hogy e szerződési feltételek akkor is kötelezőek lesznek a forgatmányosra, ha a forgatmány(ok) miatt esetleg nehezen kiolvasható a szerződés szövege, hiszen a hajóraklevél nem maga a fuvarozási szerződés, csak annak bizonyítéka.

\subsection{A hajóraklevél tartalma}

A nemzetközi egyezmények mindegyike kitér valamilyen mélységig a hajóraklevél tartalmára. A leginkább szükszavú a Hágai és a Hágai/Visby Szabályzat (III. cikk 3. pont), ugyanakkor az ezekben felsorolt elemek köre nem zárt. A legrészletesebb a Hamburgi 
Szabályzat (15. cikk 1. pont), mely szintén csak ,többek között” említ tartalmakat. Előnye, hogy itt egy helyen gyakorlatilag az összes tartalmi elem megtalálható (egy esetben kerül csak sor más cikkre való hivatkozásra). A nem teljes körüen felsorolt elemek köre kötelezö, de azok közül akár többnek az elmaradása sem érinti a dokumentum hajóraklevél mivoltát (15. cikk 3. pont), amennyiben az megfelel a szabályzat szerinti hajóraklevéldefiníciónak. A Rotterdami Szabályzat (36. cikk) ${ }^{74}$ hasonlóan részletes, azonban a Hamburgi Szabályzattal ellentétben nem mint a hajóraklevél tartalmi elemeiröl, hanem a „fuvarozási szerződés egyes részeinek" "75 fuvarokmányba történő foglalásáról rendelkezik. Mivel a dolgozat terjedelmi korlátai folytán nincsen lehetőség a hajóraklevél tartalmi elemeinek teljes körü és részletes taglalására, ezért itt csak néhány főbb elem bemutatására szorítkozom.

\subsubsection{Az áru mennyisége}

Az áru tulajdonságai közül az egyik legfontosabb az áru mennyisége. Ennek feltüntetése történhet darabszám, súly vagy térfogat meghatározásával, de az áru e jellemzőjének meghatározásához rendszerint elég egyetlen mérési módszer, melyet a fuvarozó választhat meg, többnyire a feladó által megadott adatok típusához igazodva. ${ }^{76}$ Rakodáskor a mennyiség ellenőrzésére szolgáló eszközök lehetnek a hajómerülési vagy a hajóraktérfeltöltöttségi vizsgálat, vita esetén fuvarozói oldalon hajóvizsgáló, feladói oldalon ellenőr közremüködése, bár a konténerizáció és a hajóstársasági kombinált fuvarszervezés (carrier's haulage) korszakában ezeknek a jelentősége ma már kisebb.

\subsubsection{Az áru állapota és minősége}

Míg az áru mennyiségének megállapítás a megfelelő mérőeszközök segítségével tisztázható, addig az áru állapotának meghatározása már több nehézséget okozhat. Az állapot már abban is eltér a mennyiségtől, hogy míg a mennyiséget a feladó adja meg a fuvarlevél nyomtatványon, és a fuvarozó azt csak ellenőrzi, addig az állapotot jellemzően nem a feladó, hanem a fuvarozó határozza meg. Ebből adódóan a fuvarozó vállán e kérdésben komoly felelősség nyugszik.

A fuvarozóval szemben az nem elvárás, hogy az áru állapotát részletes pontossággal határozza meg a hajóraklevélben. Állapot alatt az áru nyilvánvaló külső megjelenését kell érteni, ami ésszerü vizsgálattal külsőleg megállapítható. ${ }^{77}$ Ezt a gyakorlatban létező szabályt írásban is rögzítette immár a Rotterdami Szabályzat (36. cikk 4. pont), lehetővé téve azonban további vizsgálatot is. Ha kívülről látható, hogy az áru sérült, rozsdás, törött stb., ezt a hajóraklevélben fel kell tüntetni, de a fuvarozó nem tehető felelőssé az olyan hibáért, ami ésszerü külső vizsgálattal nem volt látható. A konténerben szállított és a csomagolt áru esetén az áru állapotára vonatkozó megállapítás gyakran nem lehetséges, ezért ilyenkor általában nem magára az árura, hanem a konténerre, illetve a csomagra vonatkozó megjegyzést fognak felvenni, melyből következtetni lehet annak áruvédö képességére. ${ }^{78}$ A csomagolás hiányosságai tekintetében elvárás a precíz leírás, az, hogy „néhány csomag sérült” nem megfelelö, de az, ami egy körülbelüli darabszámot vagy egy körülbelüli arányt jelöl meg, az már igen. ${ }^{79}$

Annak rögzítése, hogy milyen állapot jellemzi az árut, azért nagy felelösség a hajóraklevél kiállítójának, mert a hajóraklevél ezzel kapcsolatos állításai számos további következménnyel járhatnak. Ha a hajóraklevél képes tulajdonjogot megtestesíteni, akkor az áru - fuvarozás során történő - eladásának, vagy az árufedezet melletti hitelfelvételnek az lesz az alapkérdése, hogy az áru megfelelő állapotú-e. Éppen ezért a feladó alapvető célja, hogy tiszta hajóraklevelet (clean bill of lading) kapjon, amin nem szerepel az áru állapotára 
vonatkozó, negatív tartalmú állítás. Sőt, olyan kérés is előfordulhat a gyakorlatban, hogy kifejezetten „tisztán berakva” (clean on board) megjegyzéssel kérik ellátni a dokumentumot, mivel okmányos meghitelezés esetén a banknak mindkét tény igazolása fontos. ${ }^{80}$ A hajóraklevélre rávezetendő nyilatkozatokkal kapcsolatban két gyakorlati problémát érdemes kiemelni.

Előfordulhat, hogy a feladó megpróbálja rávenni a fuvarozót, hogy az ne tüntessen fel olyan megjelölést, amely az áru állapotát illetően hátrányos. Ennek felajánlása gyakran garancialevél adása (letter of indemnity) mellett történik, arra az esetre, ha utóbb az áru átvevője beperelné a fuvarozót a valós helyzet eltitkolása miatt. ${ }^{81} \mathrm{Az}$ ilyen kezességvállalási ígérettel nem érezheti magát biztonságban a fuvarozó, mivel a szabályozás ezt általában csalás folytán semmisnek tekinti, így sem perlés alóli kibúvást nem tesz lehetővé, sem a feladóval szemben nem lehet azt utólag érvényesíteni, így felajánlásuk rendszerint egyértelmü visszautasításra talál a fuvarozók körében. A nemzetközi konvenciók ${ }^{82}$ nem írják elő, hogy a feladó az áru állapota tekintetében felelne az általa megadott információk valódiságáért, ezzel eleve kizárják annak lehetőségét, hogy a feladó ez iránt garanciát vállalhasson. A Hamburgi Szabályzat (17. cikk 2. pont) ráadásul külön pontban kifejezi, hogy érvénytelennek tekinti az ilyen garanciavállalást.

A másik gyakorlati kérdés, hogy adott esetben kell-e szerepelnie és milyen fuvarozói megjegyzésnek a hajóraklevélben. Meddig minősülhet igaznak például a „látszólag jó állapotban" (apparent good order and condition) megállapítás, és mikortól van szükség arra, hogy negatív tartalmú megjegyzést vegyenek fel? A kérdést alapvetően az dönti el, hogy az áruval kapcsolatban mi szerepel a hajóraklevélben. Ha ugyanis ott az áru állapotát hitelesen, a valóságnak megfelelően írták le, akkor további hátrányos megállapítás felvétele nem feltétlenül indokolt. ${ }^{83}$ Másfelöl azonban a fuvarozónak számolnia kell annak következményeivel, ha elmulasztja az indokolt negatív tartalmú záradékok rávezetését a hajóraklevélre. Ez nem csak harmadik személyekkel szembeni felelősség alapja lesz, súlyos esetben nem kaphat megtérítést fuvarozói felelősségbiztosítása (P\&I) alapján.

Az áru állapota és az áru minősége megkülönböztetendő egymástól, utóbbi alatt az áru egyszerü, általános leírását, fajtájának megjelölését értik. E tekintetben szintén az az általános szabály, hogy nem kell teljes részletezettségre törekedni, elég, ha annak alapján az árufajta egyértelműen azonosítható. ${ }^{84}$ Az áru minőségét a konvenciók közül a Hágai és a Hágai/Visby Szabályzat külön nem említi, ellenben a Hamburgi Szabályzat megköveteli az áru általános természetének feltüntetését (15. cikk 1. (a) pont: „the general nature of goods [...]"). A Rotterdami Szabályzat az áru leírását a fuvarozásnak megfelelően követeli meg (36. cikk 1. (a) pont: „A description of the goods asappropriate for the transport; [...]”).

\subsubsection{Az áru lényeges jegyei (árujelölések)}

A mennyiségen, az állapoton és a minőségen kívül vannak még lényeges árujegyek (leading marks), melyeknek fontos szerepük van az áru azonosításában, különösen a feladón és a fuvarozón kívüli felek számára, akiknek nem lehet közvetlen ismeretük az áruról. Ezeknek a hajóraklevélben való feltüntetését a nemzetközi konvenciók is tartalmazzák. $^{85}$ Így tehát, ha a feladó szeretné, hogy valamely árujellemző fel legyen tüntetve a hajóraklevélben, és az valóban szükséges az áru azonosításához, akkor azt a fuvarozó nem tagadhatja meg. Ellenkező esetben erre nem lesz köteles.

Kérdés, hogy mely árutulajdonságok tekinthetők lényegesnek adott esetben. Egy ezzel kapcsolatos perben ${ }^{86}$ az angol Fellebbviteli Bíróság azt mondta ki, hogy amennyiben a jegyeknek nincsen kereskedelmi szempontból értelmük, és a vevőnek sem jelentenek semmit az áru természetét, minőségét vagy mennyiségét illetően, akkor számára teljesen lényegtelen lesz, hogy az árun milyen megjelölés szerepel. 
A nemzetközi egyezmények mindegyike megköveteli az azonosításhoz való szükségességet (necessary for identification). $\mathrm{Az}$ árujelölés lényeges jellegét a szabályzatok értelmében tehát az határozza meg, mennyiben szükséges az adott árujegy az áru azonosításához. Annyi eltérés azonban van közöttük, hogy a Hágai és a Hágai/Visby Szabályzat megköveteli azt is az árujegyektől, hogy azok bélyegezve vagy egyéb módon világosan szerepeljenek az árun, csomagolt áru esetében pedig úgy szerepeljen a csomagoláson, hogy az út végéig tisztán látható maradjon.

\subsubsection{A hajóraklevél kiállításának ideje és helye}

A hajóraklevél tartalmi elemei közül érdemes külön kiemelni annak dátumát. Ez a hajóraklevél kiállításának időpontját jelzi, ezért nem szabályos előre ledátumozni a hajóraklevelet, különösen, ha az áru berakodása még nem fejeződött be. A fuvarozó nem mentesülhet a (késedelem miatti) felelősség alól utólag azzal a védekezéssel, hogy a rakodást valójában később fejezték be, mint a hajóraklevélben szereplő dátum. ${ }^{87}$ Fontos azt is kiemelni, hogy a hajóraklevél dátuma nem ugyanaz, mint az árufeladás dátuma. Ez utóbbi rendszerint egy korábbi, de semmiképpen sem későbbi időpontot jelent, mint a hajóraklevél kiállítási dátuma. Ennek ellenére a hajóraklevélben mindig az árunak a feladáskori mennyiségét, állapotát, minőségét stb. kell rögzíteni. Ha ugyanis az áruban a berakodást követően, de még a hajóraklevél kiállítása előtt esik kár, az más eset, mint ha a feladó eleve sérült árut akart volna feladni. Ez ugyanis a fuvarozó terhére esik, s emiatt nem tehető a hátrányos megjegyzés hajóraklevélbe. ${ }^{88}$ Bizonyos esetekben ez a berakodás során keletkezett sérülésekre is igaz lehet (pl. a harmadik személyekért való felelösség szabályai szerint, amennyiben a rakodókat a fuvarozó bízta meg). A dátummal kapcsolatban a Hamburgi Szabályzat (15. cikk 1. (f) és 2. pont) különbséget tesz az árunak a fuvarozó általi átvételének, valamint - berakott árut igazoló hajóraklevél esetében - a hajóba rakás időpontja között. A legpontosabban a Rotterdami Szabályzat (36. cikk 2. (c) pont) határolja el az időpontokat, megkülönböztetve az áru fuvarozó általi átvételének, a hajóba rakásnak és a hajóraklevél kiállításának dátumát.

A kiállítás dátuma mellett szokott szerepelni a hajóraklevél kiállításának helye (place of issue) is. Ezzel kapcsolatban kiemelendő, hogy ez nem feltétlenül esik egybe az áru hajóba rakásának helyével (place of loading). E megkülönböztetést a Hamburgi Szabályzat (15. cikk 1. (f) és (i) pont) kifejezetten megköveteli a hajóraklevél tartalmi elemei között.

\subsubsection{A fuvarozó felelőssége a hajóraklevél tartalmáért}

Összegezve a hajóraklevél tartalmát, az mondható, hogy az olyan, mint egy ígéret arra vonatkozóan, hogy mi és milyen jellemzőkkel lett feladva, s ebben az ígéretben bíznak azok a személyek (harmadik felek), akikhez a hajóraklevél később került. A Hágai/Visby, a Hamburgi és a Rotterdami Szabályzat védi ezeket a személyeket, velük szemben a fuvarozó utóbb nem tagadhatja a rögzítetteket. Ez komoly felelősség és teher az ő számára, mellyel szemben két eszköz lehet a segítségére. Az egyik lehetőség, hogy a nemzetközi egyezmények mindegyike tartalmaz mentesülést az alól, hogy a fuvarozó olyan árujellemzőt tüntessen fel a hajóraklevélben, amelyről ésszerü okból feltételezheti, hogy az nem felel meg a valóságnak, vagy amelyekkel kapcsolatban megfelelő ellenőrző eszközök nem állnak rendelkezésére. ${ }^{89}$

A másik lehetőség a korábban már említett klauzulák alkalmazása, melyekkel azáltal csökkentheti a felelősséget a fuvarozó, hogy az adott információt a feladó adta meg. Az áru eddig tárgyalt szempontjainak mindegyikével kapcsolatban léteznek ilyen szokásos klauzulák. ${ }^{90}$ Mennyiséggel kapcsolatban használják többek között a ,feladó által megadott 
adatok” (shipper's figures), a „feladó általi berakás és mérés” (shipper's load and count), az „állítólagos súlya” (said to weigh) vagy a „súly, méret, mennyiség ismeretlen” (weight, measure, quantity/unknown) klauzulákat. Az áru állapotát illetően alkalmazott leggyakoribb záradék a „látszólag... állapotban” (apparent... order and condition). Minőségre utal az ,állítólag...” (said to be). Létezik olyan is, amely az előző kategóriák közül többre is vagy akár azok mindegyikére egyaránt vonatkozik. Ez utóbbira példa a „súly, minőség, állapot ismeretlen” (weight, quality, condition unknown). A konténerre és a csomagolásra vonatkozó megjegyzések közé tartozik az ,állítólag tartalmaz” (said to contain), „tartalma ismeretlen” (contents unknown). Az állapottal kapcsolatos klauzulák azonban annyiban különlegesek, hogy azok alkalmazásával a fuvarozó a felelősségét kevésbé tudja korlátozni, szemben például a mennyiségre vonatkozó klauzulákkal, éppen azért, mert az állapot hiteles meghatározása alapvetően az ő feladata. Egyes fuvarozóknál (pl. Maersk Line) ezért van érvényben az a gyakorlat, hogy hiába kéri a feladó, még feladó általi berakásra utaló klauzula mellett sem írnak a hajóraklevélre olyan megjegyzést, ami minőségre vonatkozik. Így például az áru leírásánál az elfogadható, hogy „,.. vegyszerek zöld hordókban”, de az nem, hogy „... vegyszerek új hordókban”, mert a „zöld” viszonylag objektív minőség, az „új” viszont nem.

A klauzulák alkalmazásának korlátja, hogy mindegyik tárgyalt konvenció érvénytelennek minősíti az olyan klauzulát, amely révén a fuvarozó a kötelezettségei megszegésével okozott kárért való felelősségét kívánja csökkenteni. ${ }^{91}$

A fuvarozók gyakorlata különböző lehet abban, melyik klauzulát alkalmazzák. Az MSC a „shipper's load, stow and count”, a Maersk Line egyrészt a „said to contain”, másrészt a „shipper's load, stow, weight and count” klauzulát használja.

\subsection{A hajóraklevél fajtái}

A hajóraklevél egyes fajtái korábban már szóba kerültek, e fejezetrészben ezt kívánom összefoglalóan bemutatni. Az áttekinthetőség érdekében itt a hajóraklevél angol nyelvü megfelelőjének (bill of lading) rövidítésére alkalmazott „,B/L” jelölést használom.

Érdemes elsőként elhatárolni a vonalhajózás és a bérelt hajózás során alkalmazott hajórakleveleket. Az utóbbi neve a charterer's B/L, melyröl külön fejezetrészben lesz szó. A továbbiakban a vonalhajózás során alkalmazott hajóraklevél-típusok bemutatása következik különbözö szempontok alapján.

\subsubsection{Hajóraklevelek a hajóraklevél formátuma alapján}

A hajóraklevél hagyományos, szokásos típusát nevezik hosszú formátumú hajóraklevélnek (long form B/L). A Nemzetközi Hajózási Kamara által szorgalmazott egyszerüsítési törekvés révén kialakult a hajóraklevélnek egy rövidebb, csak a lényeges információkat tartalmazó fajtája. Ez a rövid formátumú hajóraklevél (short form $B / L$ ), melynek hátlapja nem tartalmazza részletesen a fuvarozási szerződési feltételeket, ehelyett annak elölapja egy klauzulával (incorporation clause) utal a fuvarozó általános szerződési feltételeire. Ez a rövidség egyúttal hátránya is e típusnak, ugyanis különböző országokban kétséges lehet annak jogi megítélése, különösen azon személyek tekintetében, akikre a feladó a rövid formátumú hajóraklevelet átruházza. Ök ugyanis híján lesznek az általános szerződési feltételeknek, mely a feladó számára ismert volt, de számukra nem. ${ }^{92}$ Ennek egy további egyszerüsített változata az üres hátlapú hajóraklevél (blank back $\mathbf{B} / \mathbf{L}$ ), amely egyáltalán nem tartalmaz előre nyomtatott szerződési feltételeket, így azok esetileg határozhatók meg. 
E két egyszerüsített formátumú hajóraklevél szinte kizárólag az Amerikai Egyesült Államokban fordul elö. ${ }^{93}$

\subsubsection{Hajóraklevelek a funkciók teljessége és az átruházhatóság alapján}

E szempontból különbséget tehetünk azon hajóraklevelek között, amelyek mindhárom alapfunkcióval bírnak, és azok között, amelyek csak az áru átvétele és a fuvarozási szerződés megkötése bizonyításának funkciójával bírnak. Ez szorosan kapcsolódik a későbbiekben bemutatandó átruházhatósághoz, amely alapján különbséget teszünk az átruházható (negotiable $\mathrm{B} / \mathrm{L}$, transferable $\mathrm{B} / \mathrm{L}$ ) és a nem átruházható (non-negotiable $B / L$ ), más néven közvetlen (straight $B / L$ ) vagy névre szóló (named $B / L$ ) hajóraklevelekről. Az átruházható hajóraklevél az átruházás módját tekintve lehet bemutatóra szóló (bearer bill) vagy rendeletre szóló (order bill).

\subsubsection{Hajóraklevelek az áru vagy a csomagolás állapota alapján}

A kereskedelmi forgalom számára alapvetően fontos a tiszta (clean B/L) és a nem tiszta (unclean $\mathbf{B} / \mathbf{L}$ ) hajóraklevelek megkülönböztetése az áru vagy a csomagolás állapota alapján. ${ }^{94} \mathrm{Az}$ utóbbira használják még a piszkos (dirty $\mathbf{B} / \mathbf{L}$ ) és a szennyes (foul $\mathbf{B} / \mathbf{L}$ ) hajóraklevél elnevezéseket is. A nem tiszta hajóraklevél, hiába testesít is meg esetleg tulajdonjogot, a gyakorlatban nem lesz alkalmas arra, hogy azt átruházzák. Mivel e nem tiszta hajórakleveleket mindig valamilyen negatív tartalmú klauzulával látja el a fuvarozó, ezért gyakran nevezik azt záradékolt hajóraklevélnek (claused B/L). ${ }^{95} \mathrm{Ez}$ nem jelenti azt, hogy a tiszta hajóraklevél egyáltalán nem tartalmazhat semmilyen záradékot, csupán negatív tartalmút nem. Önmagában az, hogy az áru megfelelö állapotát nem lehetett az elvárt külső megtekintésnél alaposabb vizsgálattal is igazolni, nem teszi „tisztátalanná” a hajóraklevelet, rendszerint annyi megállapítás elegendő, hogy az áru külsőleg jó állapotban van. Még annak rögzítése sem feltétlenül érinti a hajóraklevél „tisztaságát”, hogy a mennyiség és/vagy az állapot ismeretlen a fuvarozó számára. A kifejezetten negatív tartalmú záradékok (pl. „nedves áru”, „penészes csomag”) viszont igen.

Fontos arra felhívni a figyelmet, hogy a tiszta hajóraklevél inkább elméleti kategória, azt a hajóraklevelet tekintjük ilyennek, amelyiken nem szerepel negatív tartalmú megjegyzés, ugyanakkor a gyakorlatban magán a dokumentumon az a kifejezés, hogy tiszta (clean), így kifejezetten nem szerepel, bár korábban voltak erre irányuló feladói kérések. A Maersk Line hajóraklevelén például ez azért sem szükséges, mert az kifejezetten tartalmazza a következő szöveget: „SHIPPED, as far as ascertained by reasonable means of checking, inapparent good order and condition unless otherwise stated herein [...]", azaz „FELADVA, látszólag jó állapotban, amennyire azt ésszerü vizsgálati eszközökkel meg lehetett állapítani, hacsak ettől eltérö megállapítás nem szerepel itt [...]”.

\subsubsection{Hajóraklevelek az áru átvételének helye és időpontja szerint}

Az átruházhatóság szempontjából szintén jelentős az áru átvételének helye és időpontja alapján történő különbségtétel. ${ }^{96}$ Eszerint az átvételt igazoló hajóraklevélnél (received for shipment $B / L$ ) annyival több a berakott árut igazoló hajóraklevél (shipped $B / L$ ), hogy azzal a fuvarozó az átvétel ténye mellett a hajóba rakottság - ,(shipped) on board” állapotát is igazolja, mely az előzőnél többet, biztosabb helyzetet jelent egy vevő vagy egy bank számára. Ugyanakkor, ha az átvételt igazoló hajóraklevél kiállítását követően sor került a tényleges berakásra, akkor a helyzet kétféleképpen orvosolható. Vagy úgy, hogy erre a hajóraklevélre rávezetnek egy berakásra vonatkozó megjegyzést, például az „áru 
ténylegesen berakva" (goods actually shipped on board), vagy úgy, hogy a korábbi hajóraklevelet berakott árut igazoló hajóraklevélre cserélik ki. ${ }^{97}$

A hajóraklevél átvételt igazoló és a berakást igazoló típusainak megkülönböztetése fontos az elmélet szempontjából, a gyakorlatban azonban nagyon ritkán kerül sor átvételt igazoló hajóraklevél kiállítására. Ehelyett inkább az jellemző, hogy a hajóraklevelet nem az áru átvételekor, és sokszor nem is a hajóba rakáskor, hanem csak az után állítják ki, hogy a hajó már ténylegesen el is hajózott. Ennek a megoldásnak több oka is van. Egyrészt a feladónak fontos érdeke, hogy berakást igazoló hajóraklevélhez jusson. Ha már úgy döntött, hogy hajóraklevéllel és nem tengeri fuvarlevéllel fuvaroztat, az nem véletlenül történt, hiszen a hajóraklevelet valahol, valamilyen célból fel fogja használni. Ebből következően azonban világos, hogy a hajóraklevélnek a csupán átvételt igazoló formájával a gyakorlatban nem tud továbblépni, például ez alapján nem nyitnak számára akkreditívet. A feladó érdeke a berakást igazoló hajóraklevél iránt találkozik a fuvarozó ugyanezen igényével, hiszen a fuvarozó számára is lényegesen könnyebb a berakás után egyszer hajóraklevelet kiállítani, mint egyszer az átvételkor, és még egyszer a berakáskor, vagy pedig berakás után a korábban kiállított hajóraklevélre egy „feladva” (shipped) nyilatkozatot rávezetni.

\subsubsection{Hajóraklevelek a fuvarozási mód szerint}

A konténerizáció elterjedése jelentős változásokat eredményezett a tengeri fuvarozók életében, tevékenységében, ami újabb hajóraklevél típusok kialakulását vonta maga után. E tekintetben tengeri hajóraklevélnek (ocean $\mathbf{B} / \mathbf{L}$ ) nevezzük a hagyományos, csak a kikötők közti tengeri szakaszra vonatkozó unimodális hajórakleveleket. Ha a tengeri fuvarozási ágnál maradunk, és ez több fuvareszközzel történik, átrakásos hajóraklevélről (through $\mathbf{B} / \mathbf{L}$ ) beszélünk, ${ }^{98}$ mely alkalmas arra, hogy egymaga fedezze az áru fuvarozását olyan esetben, amikor a feladási és rendeltetési kikötő közé egy átrakási kikötő - és ezáltal akár egy másik fuvarozó másik hajója - is beékelődik. Az átrakás(ok) ellenére ilyenkor a teljes fuvarszakaszra egyetlen dokumentumot állítanak ki, a teljesítésért való felelösséget vagy egyedül az átrakásos hajóraklevél kiállítója viseli, vagy az megoszlik a fuvarozók között, és mindenki csak azért a szakaszért felel, amely az ő teljesítése és irányítása alá tartozott. $^{99}$

Ha nem egy másik hajó, hanem egy másik fuvarozási mód közbeiktatására kerül sor, és hajóstársaság állítja ki a hajóraklevelet, akkor kombinált fuvarozási hajóraklevél (combined transport $\mathbf{B} / \mathbf{L}$ ) típusról van szó. A szakirodalom szerint ${ }^{100}$ Ennek a szállítmányozók által alkalmazott megfelelőjére szokták alkalmazni a multimodális fuvarozási hajóraklevél (multimodal transport B/L) fogalmát, azonban pl. a Maersk Line hajóraklevele a kombinált fuvarozás esetére ezt a kifejezést használja.

Ez a példa is jól mutatja azt, hogy a gyakorlatban a „kombinált”, a „multimodális” és az „átrakásos” fogalmak használata keveredik, s azok a mindennapok során nem különülnek el olyan tisztán, mint a fenti kategorizálás. Az ezzel összefüggésbe hozható másik fontos jelenség, hogy az egyes hajóraklevél-fajták nem feltétlenül különülnek el egymástól, illetve nem öltik fel minden esetben eltérő formanyomtatvány-típus alakját, pusztán azért, mert több fuvareszköz vagy más fuvarozási ág igénybevételével kerül sor a fuvarozásra. Kombinált fuvarozásnál például mind a Maersk Line, mind az MSC olyan hajóraklevelet használ, - de az ACL hajóraklevele, és a BIMCO Conline 2000 nevü nyomtatványtípusa is ilyen $^{101}$-, amelyen külön rovat szerepel az átvétel és a kiszolgáltatás helyének megjelölésére, arra az esetre, ha multimodális fuvarozásra kerül sor. Sőt, bár a tengeri szakaszon gyakran szükséges az átrakás más hajóra, emiatt külön átrakásos hajóraklevélnyomtatványtípus alkalmazása sem indokolt. Így ugyanaz a formanyomtatvány szolgál 
mind a csak kikötők közötti (port-to-port) unimodális, mind az átrakásos (through transport), mind a kombinált (combined transport) fuvarozáshoz, ezáltal a hajóraklevél típusát annak konkrét kitöltési módja fogja meghatározni.

\subsubsection{Egyéb hajóraklevél-típusok}

Tengeri gyüjtőáru-forgalomban alkalmazzák a gyüjtő-hajóraklevelet (consolidation $\mathbf{B} / \mathbf{L},{ }^{102}$ más forrás ${ }^{103}$ szerint service $\mathbf{B} / \mathbf{L}$ vagy groupage $\mathbf{B} / \mathbf{L}$ ). Ebben az esetben több feladót ugyanazon kikötői gyüjtőszállítmányozó kapcsol össze azáltal, hogy összegyüjti a feladók áruit, gondoskodik azok feladásáról, majd a rendeltetési helyen a kiszolgáltatásról. A szállítmányozó a fuvarozótól a teljes árumennyiségre egyetlen hajóraklevelet kap, ez lesz a gyüjtő- vagy fö (master B/L) hajóraklevél, ${ }^{104}$ mely feladóként a szállítmányozót tünteti fel, és rendszerint címzettként is őt vagy ügynökét nevezi meg. Ebből következően az ilyen hajóraklevél nem lesz átruházható. A megbízók a szállítmányozó által kiállított, valamilyen áru átvételét igazoló elismervényt kapnak. Ez gyakran házi hajóraklevél (house B/L) formáját ölti. ${ }^{105}$ Ez utóbbi okmányt maga a szállítmányozó állítja ki az általa rendszeresített formula szerint, ennélfogva a házi hajóraklevél nem tekinthető valódi hajóraklevélnek, az nem testesíthet meg tulajdonjogot, így nem rendelkezhet értékpapírfunkcióval sem. A házi hajóraklevelet a rendeltetési kikötőben a gyüjtőszállítmányozónak, vagy ottani ügynökének kell bemutatni, aki a címzettek részére a fuvarozótól begyüjti az árut és részére kiszolgáltatja. ${ }^{106} \mathrm{Az}$ általam kérdezett fuvarozók (Maersk Line és MSC) jellemzően nem foglalkoznak gyüjtőfuvarozással, de ez nem zárja ki, hogy a feladójukként eljáró szállítmányozó gyüjtőszállítmányozó legyen, aki több házi hajóraklevelet állít ki saját megbízóinak. Ö azonban az egyes árukat ilyenkor is egyben (full container load) adja fel náluk, akik ilyenkor csak egyetlen fö hajóraklevelet állítanak ki.

Előfordulhat, hogy ilyen esetben a fuvarozóvállalat felelősségvállalási nyilatkozatot kér (letter of indemnity formájában) a feladó szállítmányozótól, mellyel tudomásul veszi, hogy a fuvarozó nem vállal felelősséget az áru kiadásával kapcsolatban olyan esetben, ha vita van a szállítmányozó és az ügyfele(i) között, akik számára a speditör házi hajóraklevelet állított ki.

Csak a teljesség érdekében említem meg az expressz hajóraklevél (express B/L) fogalmát, mely nevével ellentétben nem hajóraklevél, hanem a tengeri fuvarlevél gyakorlatban előforduló megnevezése.

Az eddigi hajóraklevelek mindegyike kereskedelmi forgalomban alkalmazott dokumentum volt. Van azonban a hajórakleveleknek egy olyan köre is, amelyet a hajóstársaságok kizárólag belső vagy egymás közti viszonylatban alkalmaznak. Ezek az úgynevezett nem kereskedelmi célú hajóraklevelek (non-commercial $\mathbf{B} / \mathbf{L}$ ). Az egyik ilyen a szintén service $\mathbf{B} / \mathbf{L}$-nek nevezett, üzemi vagy vállalati hajóraklevélnek fordítható típus, amelyet akkor alkalmaznak, ha saját árut saját hajón fuvaroznak egy központból az egyes képviseletek számára, mivel a hatóságok felé akkor is el kell számolni az áruval, ha az nem szolgál viszonteladási célt. Egy másik alkalmazási esete ennek a fajtának az, amikor az egyik fuvarozóvállalat a saját hajóján egy másik fuvarozóvállalat áruját fuvarozza. Ez szintén elszámolási célt szolgál, sőt, ilyen esetben gyakran ez tekintendő a fuvarozási szerződésnek is.

Megemlítendő még a fuvarozóval üzleti társulásban álló, a fuvarozó nevében fuvarokmányt kiállítani jogosult közremüködő ügynök által használt emlékeztető hajóraklevél (memo B/L), mely az általa kiadott fuvarokmánnyal kapcsolatos lényeges adatokat tartalmazza. Ennek egy speciális változatát hívják ál-hajóraklevélnek (dummy B/L), amelyet általában valamilyen felmerült akadály kezelése és dokumentálása céljából alkalmaznak. Ilyen eset lehet például, ha a konténerek egy részét valami okból csak egy 
következő hajóval lehetett csak elszállítani: a második adag konténer berakásakor fogják ezt a köztes dokumentumot kiállítani (természetesen e megjegyzést az eredeti hajóraklevélre is rá kell vezetni).

\subsection{A hajóraklevél átruházása}

A hajóraklevél átruházása nagyon összetett kérdés, mivel azt elsősorban az egyes országok nemzeti joga szabályozza, ami sokszínü, így olykor akár egymással ellentétes is lehet. Így a hajóraklevél fogalmáról szóló részben már említettem, hogy például az Egyesült Királyságban a hajóraklevél fogalmilag átruházható dokumentum, tehát amely tengeri fuvarokmány nem bír e tulajdonsággal, az nem is minősülhet bill of ladingnek. Hasonló a helyzet Ausztráliában is. ${ }^{107}$ Ezzel szemben az Egyesült Államokban ${ }^{108}$ vagy Kanadában $^{109}$ létezik a hajóraklevélnek olyan típusa is, amely nem átruházható. Ahhoz, hogy teljes képet lehessen kapni, a hajóraklevélre vonatkozó közvetlen szabályozáson túl az egyes országok értékpapírral foglalkozó jogszabályainak rendelkezéseit is ismerni kell. A terület tehát nagyon vegyes, így e fejezetrészben csak a különféle megoldásokból leszürhető főbb elemeket van lehetőségem bemutatni.

Az átruházhatóság kérdése szorosan kapcsolódik a hajóraklevél tulajdonjogot megtestesítő funkciójához. Hozzá kell tenni, a tulajdonjog megtestesítése önmagában nem feltétlenül elegendő a jog átruházására, vannak további feltételek is, amiknek meg kell felelni. Az angol szakirodalom szerint ${ }^{110}$ az első ilyen feltétel, hogy magából a hajóraklevél tartalmából (rendszerint az elölapján feltüntetett információkból) kiderüljön, hogy az átruházható. Mivel az átruházásra csak bizonyos időszakban kerülhet sor, a másik feltétel, hogy az áru fuvarozás alatt álljon. Ez nem jelenti azt, hogy feltétlenül a tengeren kellene lennie, az átruházásra sor kerülhet a hajóraklevél kiállításától kezdve egészen addig, amíg a rendeltetési helyen a kiszolgáltatásra jogosult számára át nem adják. Az átruházás lehetősége megszünik akkor is, ha a kiszolgáltatás iránti valamilyen hatósági vagy bírósági rendelkezést (például lefoglalás iránti végzést) adnak ki, vagy valamilyen kiszolgáltatásra irányuló követelést a fuvarozó elfogad. Harmadrészt az is lényeges szempont, hogy átruházó rendelkezik-e olyan jogcímmel, ami alapján joga van átruházni a hajóraklevelet. E kérdésben is vannak különbségek egyes nemzetek szabályozásában. Így például az angol jog szerint a hajóraklevél birtoklása nem lehet több az áru birtoklásánál, így a feladó nem ruházhat át olyan jogot, amivel korábban nem rendelkezett. Ezzel szemben viszont a magyar jog, amely szintén ismeri ezt az elvet, a bemutatóra szóló értékpapírok esetében kivételt tesz. ${ }^{111}$ A negyedik feltétel, hogy az átadás valóban az áru feletti jog átruházásának szándékával történjen. Az átruházás szándéka feltételhez is köthető, például amikor az eladó a vételár teljes megfizetéséig fenntartja a feladott áru tulajdonjogát.

A hajóraklevelek körében az értékpapír-átruházási módok mindegyikére találunk példát, ezt a gyakorlatban a „címzett” rovatban feltüntetett információ fogja meghatározni. Az átruházásnak így a következő esetei fordulhatnak elö. ${ }^{112}$

A bemutatóra szóló értékpapírok (bearer bill) módjára egyszerü birtokbaadással (delivery) ruházható át a hajóraklevél, ha a címzett rovatát üresen hagyják, vagy oda azt írják be, hogy „,bemutató” (bearer) vagy „birtokos” (holder). ${ }^{113}$ Az ilyen hajóraklevél egyszerüen a másik személynek történő átadással átruházható, az árut pedig annak a személynek fogja a fuvarozó kiszolgáltatni, aki a hajóraklevelet a végén bemutatja. Ismert a hajóraklevélnek olyan típusa, ami bemutatóra szól. ${ }^{114}$

A forgatással, azaz forgatmány (indorsement) - vagy ehhez hasonló, az értékpapírra rávezetett átruházó nyilatkozat - útján történő átruházásnak nagy jelentősége van a hajóraklevelek esetében, melyek nagyon gyakran forgatható (negotiable) értékpapírok. ${ }^{115}$ A forgatás útján történő átruházás abban az esetben lehetséges, ha a 
címzetti rovatban az szerepel, hogy rendeletre (to order) vagy valaki rendeletére (to order of....). ${ }^{116} \mathrm{Az}$ átruházás ez esetben két cselekményt igényel: a hajóraklevél forgatását (endorsement, indorsement) és fizikai átadást. A feladó a forgatmány révén meghatározhatja, kinek a rendeletére kelljen az árut kiszolgáltatni. Ezen - a hajóraklevélnek általában a hátulsó részére rávezetett - átruházó nyilatkozattal név szerint meghatározhatja a jogosultat, ez az úgynevezett teljes forgatmány (special endorsement), vagy csak aláírást tesz és keltez, amit üres forgatmánynak (endorsement in blank) hívunk. Az előbbi esetben a forgatmányos is továbbforgathatja a hajóraklevelet, így végül az a személy követelheti majd az áru kiszolgáltatását, akit a forgatmányok összefüggő láncolata igazol. Ezzel szemben az üres forgatás bemutatóra szólóvá teszi a hajóraklevelet, így bármely személy jogszerü birtokos lesz, akinek a hajóraklevelet (e szándékkal) átadják, mindaddig, amíg az adott jogosult az üres forgatmányt teljes forgatmánnyá nem alakítja.

Ha a címzett rovatában a címzettet név és cím szerint feltüntetik (névre szóló hajóraklevél), akkor átadást követően egyedül e személy tekinthető a hajóraklevél birtokosának, és nincs lehetőség a hajóraklevél más személyre történő forgatására (rektapapír). Ebben az esetben átruházásra - ahol ez egyáltalán lehetséges - legfeljebb cesszió révén, az engedményezés (assignment) szabályai szerint kerülhet sor.

Ez utóbbi két átruházási módnak találtam ${ }^{117}$ egy vegyes változatát, amikor a címzett neve mellett azt is feltüntetik, hogy „,vagy rendeletére” (... or to order). Ez lehetővé teszi, hogy a címzett más személyre forgassa a hajóraklevelet, amit a forgatmányos nem forgathat tovább, kivéve, ha a címzett a forgatáskor a forgatmányos neve mellett szintén feltünteti a „vagy rendeletére” szöveget.

Amikor a hajóraklevelet sorozatban állítják ki, mindegyik példány eredetinek minősül, így fennáll annak kockázata, hogy azokat egymástól függetlenül ruházzák át különböző személyekre. Ennek elkerülése érdekében általában az a szabály érvényesül, hogy a sorozat bármelyik eredeti példányának megfelelő átruházása elegendő a jog átruházásához. Ebből két dolog következik. Egyrészt az, hogy az átruházáshoz nem szükséges valamennyi hajóraklevelet a másik személyre forgatni, és ennek a személynek az áru kiszolgáltatásakor elegendő lesz ezt az egy példányt bemutatni. Másrészt pedig egy eredeti példány jogszerü átruházása esetén a többi példány ezt követő átruházásának semmilyen hatálya nem lesz az áru tulajdonjogára nézve, és nem érinti annak jogát, akire elsőként forgatták a hajóraklevelet. ${ }^{118} \mathrm{Nem}$ minden fuvarozó esetében érvényesül azonban a fenti általános szabály, erről a hajóraklevél bemutatásával kapcsolatos problémák körében fogok szólni.

Végezetül meg kell említeni, hogy az átruházással kapcsolatban a konvenciók közül egyedül a Rotterdami Szabályzat tartalmaz viszonylag bővebben rendelkezéseket. A definíciók körében több helyen is (1. cikk 10., 15-16., 19-22. pont) szól a nem átruházható és az átruházható, ez utóbbin belül pedig a forgatható, az üres forgatmánnyal ellátott és a bemutatóra szóló fajtákról. Átruházhatóság esetén a szabályzat megköveteli e minőség kifejezett feltüntetését. A jogok átruházásáról szóló 11. fejezetben pedig az átruházás két fó esetét szabályozza, a forgatást (mind teljes, mind üres forgatmánnyal), valamint a forgatmány nélküli átruházást. Értve ez utóbbi alatt egyfelől a bemutatóra szóló és az üres forgatmánnyal rendelkező dokumentum - minden bizonnyal birtokbaadással történő átruházását, másfelől átruházási esetnek veszi azt az esetet, amikor a névre szóló hajóraklevelet annak első birtokosa (a feladó) átadja a megnevezett címzettnek (57. cikk).

\subsection{A hajóraklevél bemutatása, problémák a bemutatás során}

Ha az áruról hajóraklevelet állítottak ki, az áru kiszolgáltatására jogosult személy azt a hajóraklevél bemutatása ellenében kaphatja meg. Ennek a rendszernek az érvényesülése egyfelől védi a jogosultat azáltal, hogy a fuvarozó más esetben nem szolgáltathatja ki a 
küldeményt, így az más személyhez nem kerülhet. Másfelől a hajóraklevél bemutatása a fuvarozó számára is jelentős cselekmény lesz, mivel annak következtében az áru kiszolgáltathatóvá válik, mellyel a fuvarozó a fuvarozási szerződésből eredő utolsó alapvető kötelezettségének is eleget tud tenni.

Ha a fuvarozót tekintjük, kedvezőbb helyzetben van akkor, ha nem átruházható típusú hajóraklevéllel fedezik az árut, mert így az abban egyértelműen megnevezett címzett részére kell teljesítenie. ${ }^{119} \mathrm{Ha}$ azonban a hajóraklevél átruházható, akkor a rendeltetési kikötőben lehet, hogy egy olyan személy fogja követelni az árut, aki számára addig ismeretlen volt. Fennáll tehát a veszélye annak, hogy tévedésböl nem a valódi jogosultnak szolgáltatja ki az árut, melynek következményeiért felelőssé tehető. Ha már átruházható hajóraklevéllel áll szemben, talán az az egyszerübb számára, ha az bemutatóra szól. Ilyenkor ugyanis a mindenkori birtokosnak kell kiszolgáltatni az árut, ami jóval könnyebb eset, mint a forgatással átruházott dokumentumon szereplö forgatmányok láncolatában felfedezni az esetleges problémát.

A hajóraklevél bemutatásával kapcsolatban több konkrét gyakorlati probléma adódhat, a következőkben ezeket kívánom áttekinteni.

\subsubsection{A hajóraklevél bemutatásával kapcsolatos általános problémák}

Az első ilyen eset, ha a rendeltetési kikötőben az áru kiszolgáltatását követelő személy nem tud hajóraklevelet bemutatni. ${ }^{120}$ Ennek tipikus példája az, ha ez a személy az alapügylet vevője, aki még nem fizetett az áruért, így - bár az áru már megérkezett - a hajóraklevél még nem ért oda. A hajóraklevél be nem nyújtásának oka az is lehet, hogy a feladó valójában más félnek adta el az árut, mint aki az áru kiszolgáltatását követeli. A fuvarozónak minden ilyen esetben vigyáznia kell: a hajóraklevél nélküli kiszolgáltatás általában súlyos szerződésszegésnek minősül. A vitás helyzetet csak a két fél tudja rendezni, és addig a fuvarozónak nem szabad kiszolgáltatnia az árut, különben korlátlan és egyetemleges felelősséggel fog felelni a károsult felé. A fuvarozó ezzel nem csak a fuvarozási szerződést szegné meg, a kiszolgáltatással a hajóraklevél-birtokos tulajdonjoga is sérül. Mindezek miatt a fuvarozó perelhető lesz, ráadásul e cselekmény rendszerint a fuvarozói felelősségbiztosítási szabályok megszegését is jelenti. A fuvarozási szerződések kifejezetten hajóraklevélhez kötik a kiszolgáltatást, így ha a fuvarozó erre nincsen tekintettel, garancialevél mellett is szerződésszegés valósul meg, még akkor is, ha ez esetleg megfelelne a helyi kereskedelmi szabályoknak vagy gyakorlatnak. ${ }^{121}$ Ha tehát nem tudnak megfelelö hajóraklevelet bemutatni, az árut rendszerint kikötői vagy közraktárban helyezik el a helyzet tisztázásáig, mely többletköltségek megtérítését a fuvarozó követelni fogja.

Hasonló a helyzet akkor, ha az árut olyan kikötőben kérik kiszolgáltatni, ami nincs feltüntetve a hajóraklevélben. A fuvarozó felelőssége az előzőekben ismertetettek szerint alakul, annyival kiegészítve, hogy a másik kikötőben történő árukiszolgáltatás jogtalan kitérésnek (deviation) minősülhet.

Komoly problémát jelent, ha egynél többen követelik az áru kiszolgáltatását. Ez akkor eshet meg, ha a hajóraklevelet sorozatban, több eredeti példányban állították ki, és az eredeti példányok több személy kezébe kerültek. Emiatt a fuvarozók saját védelmük érdekében gyakran alkalmazzák a hajóraklevélen az „egy példány bemutatása esetén a többi érvénytelennek tekintendő" (one being accomplished, the others to stand void) szövegű klauzulát. ${ }^{122}$ A felelősség korlátozásának e módja azonban még nem véd meg mindenfajta visszaéléstöl, így könnyen előfordulhat olyan csalás, hogy a hajóraklevél birtokosa azután, hogy a hajóraklevél egyik példányát hitelfelvétel biztosítékaként egy bankra forgatja, az árut mégis egy másik - a forgatás miatt érvénytelenné vált - eredeti 
példány bemutatásával a fuvarozótól kiváltja. A fuvarozó általában nem tehető felelőssé, ha jóhiszemüen szolgáltatta ki az árut, és alapos okból feltételezhette, hogy az árut követelő személy a jogszerü hajóraklevél-birtokos. Ha azonban tudatában van a visszaélésnek, és ennek ellenére kiszolgáltatja az árut, az ezért való felelösséget viselnie kell. ${ }^{123}$ Onnantól kezdve ugyanis, hogy egy másik követelés is érkezik hozzá, őt úgy kell tekinteni, hogy értesítették, emiatt neki meg kell vizsgálnia annak lehetőségét, hogy a korábban bemutatott hajóraklevél esetleg nem érvényes.

Az árunak más esetekben is elképzelhető, hogy több követelője akad. Ilyen például, ha az eredeti hajóraklevél(-sorozat) helyett szabálytalanul úgy állítottak ki újat, hogy az eredetit nem szolgáltatták vissza, vagy ha a feladó a mögöttes adásvételi szerződés eladójaként már a címzettre mint vevőre átruházta a hajóraklevelet, de az nem teljesítette szerződéses kötelezettségeit. ${ }^{124}$

Előfordulhat, hogy a hajóraklevelet nem az elóírt formában mutatják be, például eredeti példány helyett annak faxon küldött vagy fénymásolt változatát nyújtják be. Mivel a hajóraklevél lényegi eleme az, hogy csakis annak bemutatása ellenében lehet az árut kiadni, különös tekintettel annak értékpapír-funkciójára, mindig az eredeti példányt kell megkövetelnie a fuvarozónak. ${ }^{125}$

Viszonylag újabb keletű probléma a gyakorlatban a hajóraklevél megérkezésének késedelme. Ez a fuvarozás minden szereplöje számára egyaránt nehézséget okoz. A fuvarozónak azért, mert neki hivatalosan ragaszkodnia kell a hajóraklevél bemutatásához. Az adott árufajtának a kikötőben való tárolása is nehézségbe ütközhet. Az áru kiszolgáltatására jogosultnak a késedelem az áru minőségi romlásának és a piaci árak kedvezőtlen változásának kockázatát hordozza. Bérelt hajózás hajóbérlője a hajóálláspénz fizetésével és késedelemmel szembesülhet, a hajó bérbeadója pedig esetleg lemaradhat egy másik hajóbérlő érdeklődéséröl. ${ }^{126}$

A hajóraklevél késedelme több okból is előállhat. A feladó és a címzett közötti vitán kívül előállhat ilyen helyzet akkor, ha a távolság nem kifejezetten nagy, és akkreditíves ügyletről van szó. Ilyenkor a banki folyamat időtartama a szigorú vizsgálat miatt hosszabb lehet, mint a tengeri fuvarozás ideje, kombinált fuvarozás esetén még az utófuvarozással együtt is.

Ha nem akkreditív miatt, hanem más okból (pl. kézbesítési késedelem miatt) nem ér oda időben a hajóraklevél, gyakran alkalmazott megoldás, hogy a feladó a teljes eredeti sorozatot visszaadja a fuvarozóvállalatnak, amely azt bevonja, és a rendeltetési kikötőben lévő irodának küld egy elektronikus felszabadító üzenetet („telex release”) arról, hogy nem kell bemutatni az eredeti sorozatot. A felszabadító üzenet formailag ma már egy egyszerü e-mail, de megmaradt a hagyományos neve, ami jelzi, hogy régen az irodák telexkapcsolatban voltak egymással.

A gyakorlat felöl jelzett egyik probléma a hamisítás, aminek a száma a gyakorlatban elenyésző, és az eddig előforduló esetek többségében a biztonsági intézkedések révén ez kiszürhető. Ennél gyakoribb probléma a forgatással kapcsolatos szabályok nem megfelelő alkalmazása. Van fuvarozó, aki szigorúan szabályozza a forgatás rendjét, azt, hogy különböző hajóraklevél-típus esetén ki(k) általi forgatást és aláíást vár el. ${ }^{127}$ Ugyanakkor a forgatmány a jellegéből adódóan olyan, hogy egy bizonyos szintnél mélyebben a fuvarozó rendelkezésére álló eszközökkel nem ellenőrizhető. Mivel a forgatmány csak egy rövid átruházó nyilatkozatból, aláírásból (és pecsétből) áll, a fuvarozónak a vizsgálatra vonatkozó kötelezettsége addig terjed, hogy ezek meglétét, több forgatmány esetén ezek összefüggő láncolatának meglétét ellenőrizze. Egy céges pecsét valódiságát vagy a pecséttel a kezében eljáró személy jogosultságát nem tudja vizsgálni. Így ezekért mindaddig nem felel, amíg jóhiszemüen jár el. 


\subsubsection{A sorozatban kiállított hajóraklevél bemutatásával kapcsolatos kérdések}

Sorozatban kiállított hajóraklevél esetén általában elegendő egyetlen eredeti példányt bemutatni, aminek következtében azonban a sorozat minden példánya érvényét veszti. Ez a helyzet a Maersk Line esetében is, ahol a bemutatott példányt lepecsételik egy „teljesítve” (accomplished) szöveggel és dátummal. Amellett, hogy egyetlen példány elég, az is szól, hogy adott esetben az áru kiszolgáltatását kérő személy nem is tudná a teljes sorozatot bemutatni, például mert akkreditíves tétel volt, és a bank megtartott egy eredeti példányt. A bemutatás megtörténtét a fuvarozó informatikai rendszere is rögzíti, így egy másik eredeti példány bemutatása esetén az jelzi, hogy korábban már sor került az áru kiszolgáltatására, így a szóban forgó sorozat érvénytelenítve lett.

Az MSC ezzel szemben más gyakorlatot követ: alapesetben valamennyi eredeti példányt kérik a bemutatáskor, kivéve, ha mind a feladó, mind a címzett, mind az értesítendő fél (notify party) ugyanaz a személy, amikor is elegendő csak egyetlen példány. Minden más esetben az összes eredeti példány bemutatása szükséges, ehhez tehát már az is elég, ha csak az értesítendő fél személye különböző, hiába ugyanaz a feladó és a címzett személye. Tovább bonyolítja a helyzetet, ha a hajóraklevél forgatható, ilyen esetben azt is elöírják, hogy a forgató fél kifejezetten lemondjon az áru iránti követelésről. Ez egyébként nem csak a fuvarozó, de a forgatmányos számára is biztosítékot jelent.

Akár egy, akár az összes eredeti példány átadása szükséges, bemutatás után mindig bevonják a teljes eredeti sorozatot.

\subsection{Hajóraklevél bérelt hajózás esetén}

A tengeri fuvarozás fajtái körében már esett szó arról, hogy bérelt hajózás esetén is sor kerülhet hajóraklevél kiállítására. Erre a hajóraklevélre sok szempontból egyedi szabályok vonatkoznak, ezek közül szeretném néhány fontosabbra felhívni a figyelmet.

A legelső, hogy a nemzetközi egyezmények egységesek abban, hogy hatályuk alapesetben nem terjed ki a bérelt hajózásra, onnantól kezdve azonban, hogy a hajóraklevélnek más személy lesz a birtokosa (holder), mint a hajóbérlő, a szabályzatok alkalmazandók lesznek. ${ }^{128}$ Érdekesség ebből a szempontból, ha a Hágai és a Hágai/Visby Szabályzat V. cikk 2. mondatát és III. cikk 3. pontját együttesen alkalmazzuk. Eszerint olyan helyzet állt elö, hogy bérelt hajózás esetén a bérlő e szabályzatok alapján ugyan nem követelheti hajóraklevél kiállítását, ámha úgy döntenek a felek, hogy arra mégis sor kerül, akkor azt a szabályzatoknak megfelelően kell kiállítani.

Egy másik fontos szempont, hogy a bérelt hajózás esetén eltérően alakul a helyzet akkor, ha a hajóbérlő feladóként a saját áruját szállítja a bérelt hajón, mint amikor egy tőle különböző személy a feladó. Ha az első eset áll fenn, és a hajóbérlő igényli, hogy saját árujának mennyiségéről és állapotáról igazolást kapjon, az ilyenkor kiállított hajóraklevél három helyett csak két funkciót tölthet be. Egyrészt átvételi elismervény lesz a feladott áruról, másrészt tulajdonjogot megtestesítő okiratként is felhasználható, azonban a hajóraklevél nem lehet bizonyítéka fuvarozási szerződésnek, mivel a bérlö és a hajótulajdonos közötti viszonyt nem egy fuvarozási, hanem a bérleti szerződés szabályozza.

Ezzel szemben olyankor, amikor az áru feladója nem a hajóbérlő, hanem egy harmadik fél, a kiállított hajóraklevél már bizonyíték lesz a harmadik féllel kötött fuvarozási szerződésre, de ilyenkor problémás lehet annak eldöntése, hogy a konkrét esetben a hajótulajdonos vagy a hajóbérlő minősül fuvarozónak. ${ }^{129}$ A bérelt fuvarozásra vonatkozó szerződés általában úgy rendelkezik, hogy a hajóskapitány (ma már gyakrabban a hajótulajdonos más ügynöke) a hajóbérlő útmutatásai alapján állítja ki a harmadik fél számára a hajóraklevelet. 
Mivel pedig a hajóraklevelet a hajótulajdonos képviselője írja alá, így rajta keresztül alapesetben a hajótulajdonost kell fuvarozónak tekinteni. Ez akkor is így van, ha a fuvarozást a feladóval előzetesen a hajóbérlő és nem a hajóskapitány (vagy más ügynök) egyeztette. Vannak azonban olyan esetek is, amikor a hajóbérlőt kell fuvarozónak tekinteni. Ilyen, amikor az ő nevében került sor a hajóraklevél kiállítására (ő maga állította azt ki), ${ }^{130}$ de akkor is, ha csak aláírta a hajóraklevelet, és nem tüntette fel, hogy másnak (hajóskapitány, hajótulajdonos) a nevében járt el. Különleges a helyzet, amikor a hajóskapitány a bérleti szerződés alapján nem a hajótulajdonos, hanem a hajóbérlő nevében nem jár el, ilyenkor az általa kiállított hajóraklevél fuvarozójának szintén a bérlőt kell tekinteni. Mindazonáltal a bérlőnek - még abban az esetben is, ha ő állította ki a hajóraklevelet - vannak eszközei arra, hogy áthárítsa a felelösséget a fuvarozóra. Ezek közé tartozik a hajóraklevélbe felvett bérleti klauzula (demise clause) vagy a fuvarozó személyét azonosító klauzula (identity of carrier clause), bár ezek jogi megítélése nem feltétlenül kedvezö. ${ }^{131}$

Különösen időbérlet esetén, amikor a hajóskapitány a bérlő utasításait tartozik követni, sajátos helyzet alakulhat ki a tiszta - nem tiszta hajóraklevelek kiadásának kérdése körül. A vonalhajózással ellentétben itt nem csak a feladó, hanem a bérlő oldaláról is érkezhet nyomás a hajóskapitány felé a tiszta hajóraklevél kiállítására. ${ }^{132}$ Az ezzel kapcsolatos kérdéseket - köztük annak eseteit, mikor utasíthatja vissza a hajóskapitány a hajóraklevél kiállítását - a bérleti szerződés szabályozza általában, de így is komplikált helyzet alakulhat ki a hajóraklevél kiállítása körül, és a szabályok megszegése esetén az azért való felelősség kérdésében.

\section{A hajóraklevél jövője}

\subsection{A hajóraklevél szabályozási környezetének változása}

A szabályozási környezettel kapcsolatban megállapítható, hogy a jelenlegi rendszer nem korszerü, és megújításra szorul, elsősorban azokra a kötöttségre tekintettel, amit a hajóraklevél papír-alapú formájához való - napjainkig jellemző - ragaszkodása okoz, miközben az információs technológia jelenlegi fejlettségi szintjén ennek megléte már nem indokolt. Ezzel szemben ma, az internet világában, a hajóraklevelet még mindig - a szigorú biztonsági elöírásoknak megfelelően - ki kell nyomtatni, alá kell írni, le kell pecsételni, fizikailag át kell adni, be kell mutatni, majd be kell vonni. A kicserélést is megfelelően kell adminisztrálni. Gyakorlati oldalról nézve ez számos gondot okoz: költséges az előállítás, fennáll az elvesztés lehetősége, ugyancsak a hamisítás veszélye, oda kell figyelni a biztonsági szempontokra - ez mind kihívást jelent és terheli az ágazatot.

A hajóraklevél környezetével összefüggésbe hozható problémák között említhető még a bankok lassan változó gyakorlata, különösen az akkreditív esetén támasztott nehézkes, sokszor feleslegesnek tünő előírások okozhatnak jelentős nehézséget a fuvarozás számára. Ezért ajánlott az ügyfélnek időben közölnie ezeket a banki elvárásokat a fuvarozóval. A bankok egy része sokszor elavult nyomtatványokat használ, egyes fuvarozók elmondták, sokáig tartott például az is, hogy „leszokjanak” a „clean” szövegnek a hajóraklevélben való feltüntetésének igényléséről. A gyakorlatban a problémát sokszor az okozza, hogy az ügyfelek és a fuvarozók is hajlamosak a banknak szó nélkül teljesíteni az elvárásait, így a bank sem kap mindig visszajelzést arra vonatkozóan, hogy amit kér, az már adott esetben szükségtelen, elavult, vagy nem felel meg az aktuális kereskedelmi egységesítő szabályozóknak (pl. UCP 600). 


\subsection{A hajóraklevél kiállítása iránti igény változása}

A gyakorlatban mind a Maersk Line, mind az MSC tapasztalata az, hogy az ügyfelek még mindig jelentős számban fedezik a rakományt hajóraklevéllel (körülbelül 60-65\%-a a fuvarozásnak hajóraklevéllel, 35-40\% tengeri fuvarlevéllel történik). Az arány alakulását több tényező befolyásolhatja.

Ezek közül alapvető a feladó és a címzett közötti bizalom: akik több éve fontos partnerek egymás számára, azok viszonyában nem feltétlenül szükséges az a biztosíték, amit a hajóraklevél tud kínálni értékpapír-funkciója folytán, míg ismeretlen partnerek között ez a plusz felértékelödik.

A bizalom nem csak a partnerek viszonyát illetően fontos, hanem a célország megítélésében is, melyet a mindenkori gazdasági helyzet is befolyásol. A feladó felteszi a kérdést: mennyire megbízható az az ország, ahová fuvaroztatok? Mi a garanciája, hogy megkapom az áru ellenértékét? Gyakorlati tapasztalat, hogy egyes országokba történő exportot nagyobb arányban fedeznek hajóraklevéllel. Ilyen szempontból bármely ország számára tanulságos lehet, hogy külső gazdaságpolitikai megítélése az országba irányuló, hajóraklevéllel fedezett ügyletek számában is kifejeződhet.

A bizalom mellett a kérdést befolyásolhatja a feladó személye is, egyrészt annak nagysága, piaci ereje is. Egy nagyobb multinacionális cég - részben kapcsolati tőkéje révén is kevesebbet kockáztat, ha nem hajóraklevéllel fedezi a küldeményt, mint egy kisebb cég. Másrészt egy globális vállalat esetében gyakran előfordul anya- és leányvállalatok közötti fuvarozás, mely esetben szintén elegendő fedezet a tengeri fuvarlevél. Az is fontos szempont lehet, hogy a feladó egyéni ügyfél vagy szállítmányozó: a gyakorlatban az előbbi esetben inkább jellemző hajóraklevél iránti igény, míg tengeri fuvarlevél alkalmazására inkább akkor kerül sor, ha a feladó szállítmányozó.

A hajóraklevél intézményének fennmaradását a banki gyakorlat is elősegíti: akkreditív megnyitásának feltétele tipikusan a hajóraklevél (méghozzá annak berakást igazoló formája), ehhez tengeri fuvarlevél, de még átvételt igazoló hajóraklevél sem lesz elegendő. Ez összefüggésben van a felek közti, illetve az ország iránti bizalom kérdésével: ha például valakinek a partnere rendszeresen késedelmesen fizet, akkor a feladó inkább bevon egy bankot, a fuvarozás így már hajóraklevelet fog igényelni. Ugyanígy kapcsolódik a feladó személyéhez is, hiszen egy kisebb cég tőkehiányos volta miatt gyakran igényel okmányos meghitelezést.

További lehetséges ok az, hogy a feladó mennyire járatos tengeri fuvarozásban. Aki tisztában van azzal, hogy feladóként számára a hajóraklevél a tengeri fuvarlevélhez képest jóval több jogot biztosít a fuvarozóval szemben, ha a feladott áru fuvarozás során megsérül, annak még akkor is megéri a költségesebb és több adminisztrációval együtt járó hajóraklevéllel fedezni az árut, mint tengeri fuvarlevéllel. Végül pedig a kérdést befolyásolhatja az egyes országok jogi szabályozása is.

Nehezen megbecsülhető annak aránya, hogy a hajóraklevelek mekkora aránya átruházható és mekkora aránya közvetlen hajóraklevél. Hasonló a helyzet a „hajóraklevél - tengeri fuvarlevél" dilemmához. Alapvetően itt is a felek közötti és a célország iránti bizalom kérdése, valamint a feladó személye befolyásolja a kérdést. Ez utóbbival kapcsolatban új szempontként az emelhető ki, hogy kereskedői feladóról van-e szó vagy sem. Kereskedő esetén ugyanis nagyobb az aránya az átruházható hajóraklevélnek, tekintettel arra, hogy ő az árut csak teríti, ezért azt átvenni nem ő fogja, hanem a vevő.

A Maersk Line és az MSC azt tapasztalták, hogy talán egy enyhe, lassú növekedés tapasztalható a tengeri fuvarlevéllel fedezett ügyletek számában, de jelenleg még mindig egyértelmüen magasabb a hajóraklevél iránti igény. Hosszú távon várhatóan változni fog 
majd a rendszer, de nem elsősorban a hajóraklevél müködési elve miatt, inkább annak gyakorlati alkalmazásának módját illetően.

\subsection{A hajóraklevél értékpapír-funkciójának jövője}

A hajóraklevél legfontosabb előnye a tengeri fuvarlevéllel szemben az értékpapír-funkció. Ez az a többlet, ami az előző fejezetrészben említett felek közti bizalom kérdésével összefügg, és ez a döntő meghatározója a hajóraklevél iránti igény alakulásának, ugyanakkor ez teher is a fuvarozó számára. A hajóraklevél értékpapír-funkciója az, ami megköveteli a fokozott biztonságot, és így e biztonsági követelményeknek való megfelelés többletteherrel és többletköltséggel jár a fuvarozó számára, mindez pedig drágítja a fuvarozást. A problémát megoldhatná az elektronikus hajóraklevél bevezetése - biztonsági szempontoknak természetesen ekkor is meg kellene felelni -, de ennek részben az is akadálya, hogy jelenleg a fuvarozásban érintett országok nem mindegyike rendelkezik az ehhez szükséges, megfelelő szintű infrastruktúrával.

A fuvarozói terhek csökkentésére olvasni a szakirodalomban ${ }^{133}$ egy olyan alternatív megoldásról, ami egy központi nyilvántartási rendszer felállítását képzeli el. Eszerint a hajóraklevelet a feladó rögtön a kiállítás után letétbe helyezné ebben a regiszterben. Ezt követően nem kerülne sor többé a dokumentum fizikai átadására, és a későbbi tranzakciókat a regiszterben vezetnék. A messzebb menő elgondolások szerint e rendszer arra is alkalmas lenne, hogy a fuvarozók ebben regisztráltassák a fuvarozási szerződés szerinti járó, még kifizetetlen díjakat, vagy a bankok az akkreditívvel összefüggő hitelbiztosítékot. A fuvarozónak az érkezés előtt 48 órával értesítenie kellene a regisztert, amely pedig a kiszolgáltatásra jogosultat értesítené 24 órával a várható érkezési idő előtt. Az átvevő személyéről való értesülés után a regiszter lezárna, további tranzakciót nem lehetne elvégezni, és a fuvarozó megkapná az utasítást arra vonatkozóan, kinek szolgáltathatja ki az árut.

E központi rendszernek kétségtelen előnyei mellett azonban lennének hátrányai is, illetve felvetne további kérdéseket. A hátrányok közül elsősorban annak költségessége említendő, ezzel kapcsolatban pedig rögtön az is, hogy mennyiben drágítaná ez a fuvarozás rendszerét, és kinek kellene viselnie a költségeket. Kérdés, hogy egyetlen központ léteznee vagy több helyi központ hálózatából épülne fel a rendszer. A jogi problémák közé tartozik például, hogy mi történne akkor, ha a központ vétene hibát a regiszterben, illetve vita esetén melyik legyen az alkalmazandó jog, nemzetközi egyezmény. A státusza sem világos teljesen, bár leginkább egy, a fuvarozóktól és a fuvaroztatóktól is egyaránt független szervezet lenne e feladatra a legalkalmasabb. Az önállóság, a világméretü kiterjedés és a finanszírozás kérdései miatt egy ilyen központ felállítására nagy valószínűség szerint egy nemzetközi egyezmény keretében kerülhet majd sor.

\subsection{Elektronikus hajóraklevél, IT-alapú támogatás}

A hajóraklevél elektronikus formája széleskörü használatának megvalósulását nemcsak a fuvarozók által említett problémák (költségesség) indokolják. A számítástechnika a mai fejlettségi szintjén már lehetőségek sorát kínálja az e-hajóraklevél alkalmazására. A Rotterdami Szabályzat is alapos előkészületeket tett az elektronikus forma befogadására, alkalmazásával kapcsolatos kérdések szabályozására (1. cikk 10. pont, 9. cikk 1. pont, 4547. cikkek). Mindezek ellenére a hajóraklevél jelenlegi formájához mind a mai napig erös ragaszkodás tapasztalható, ami ellene hat e folyamatnak.

Ezek alapján nem volt meglepő, hogy sem a Maersk Line, sem az MSC nem alkalmaz elektronikus hajóraklevelet, mindkét fuvarozó azt tapasztalta, hogy a mai napig nagyobb a 
jelentősége a papír-alapú hajóraklevélnek, mint az elektronikusnak. Véleményük szerint a papír-alapú hajóraklevél az abban megtestesített jog kézzelfoghatósága miatt vonzó, ezzel szemben az elektronikus jel alkalmazása iránt még nagy a bizalmatlanság. Az informatikai fejlettség és támogatás ugyan megvan hozzá, de még várni kell, hogy a mentalitás is változzon. A Maersk Line alkalmaz egy olyan megoldást, hogy a kiemelten megbízható ügyfelek számára lehetőséget biztosítanak arra, hogy a hajóraklevelet ne a vállalat, hanem otthon az ügyfél maga nyomtassa ki, mentesítendő őt az állandó személyes ügyintézés terhe alól. Ilyen esetben is vezetik azonban, hogy melyik sorszámú hajóraklevél-sorozatot kapta meg, illetve az ügyfélnek nyilatkozatot kell tennie arra nézve, hogy teljes felelősséget vállal azokért a következményekért, melyek a példányok elvesztéséből vagy elrontásából adódhatnak.

Az elektronikus forma elterjedésének kulcsa tehát minden bizonnyal az elfogadottság

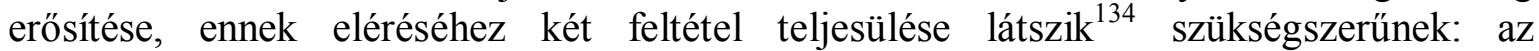
elektronikus forma egyrészt képes legyen a hagyományos hajóraklevél-funkciók mindegyikének ugyanolyan szintű reprezentálására, másrészt jogi tekintetben is azonos megítélés és elismerés alá essen, mint a papír-alapú hajóraklevél, valamint ehhez kapcsolódóan a tengeri hajóraklevél elektronikussá alakítását (dematerializálás) is meg kell oldani. $^{135}$ A Rotterdami Szabályzat megteremtette az alapokat a papír-alapú és az elektronikus hajóraklevél közötti ekvivalenciára, illetve a Comité Maritime International is

fogadott el szabályzatot az elektronikus hajóraklevelekről. ${ }^{136}$ A gyakorlatban is vannak már alkalmazásai az elektronikus dokumentációnak ${ }^{137}$ (pl. az Atlantic Container Line rendszere)

Az IT-alapú támogatást minden fuvarozóvállalat saját fejlesztésủ informatikai rendszere és honlapja jelenti: az ügyfelek annak használata révén töltik fel a hajóraklevél kiállításához szükséges adatokat. A Maersk Line ügyfelei a honlap segítségével tudnak könyvelni és feladói instrukciókat adni, az MSC esetében pedig árajánlatot is a honlapon keresztül tudnak kérni.

\section{Befejezés}

E dolgozat megírásával kísérletet tettem arra, hogy összefoglaljam a hajóraklevéllel összefüggésbe hozható legfontosabb kérdéseket, problémákat.

A vizsgálat végére azt lehetett leszürni, hogy a hajóraklevél intézménye alapvetően „nincs veszélyben”. Látható, hogy az igény továbbra is erősen kötődik a hajóraklevél értékpapírfunkciójához. Az összes korábbi szempont közül itt a bizalmat emelném ki még egyszer. Ha más nem, a világgazdaság müködése, az időnként előforduló recessziók időről-időre próbára teszi a gazdasági szereplők bizalmát. A biztonságra való törekvésben e funkció ma is jelentőséggel bír. Ennek hátránya ugyanakkor, hogy a jelenlegi környezethez való ragaszkodás túl merev, ami sokszor feleslegesen terheli az ágazatot. A helyzeten való jobbítás nem mindig igényelne nagy változtatásokat, olykor csak a régi, rugalmatlan gyakorlatokat kellene elhagyni, vagy a kor igényeihez jobban igazítani.

A nagyobb lépések megtételéhez pedig sokszor nincs meg a kellö bátorság vagy az akarat a szereplőkben. A gyakorlati alkalmazási problémákat látva sokakban biztosan megvan az igény és a motiváció a változtatásra, valami el is indul, de az átfogó reform valahogy mégis elmarad. A Rotterdami Szabályzat jól példázza ezt: az aláíró országok száma ma már több is, mint ami minimum szükséges, a kézjegyeket mégsem követi elegendő ratifikáció, így a korszerünek szánt, a modern kor kihívásaira is tekintettel lévő egyezmény hatályba lépése a belátható időn túl van. A rendszer lassúságán túl a változástól és az érdekek sérülésének lehetőségétől való félelem is oka ennek, hosszú távon ez azzal a veszéllyel jár, hogy mire alkalmazni lehetne, talán már meg is kérdőjeleződik az aktualitása. 
Ugyanígy messzinek tünik jelenleg az elektronikus hajóraklevél bevezetése. Ha nem élünk a korunk kínálta informatikai lehetőségekkel, és nem állunk e téren a változások élére, okkal tarthatunk attól, hogy a számítástechnika elönyeit mások fogják a maguk javára használni. És akkor előfordulhat, hogy már nem csak gyenge hajóraklevél-utánzatok jelennek meg, mint ma az esetek többségében.

${ }^{1}$ Hernád Ágnessel, a MAERSK HUNGARY Kft. ügyvezető igazgatójával készített interjú (2012. április 26.)
2 Varga Ildikóval, az MSC Magyarország Kft. kereskedelmi vezetöjével készített interjú (2012. április 24.)
${ }^{3}$ Koszonits-Potocska-Pozsgai: Nemzetközi szállítmányozás, 2. köt. Magyar Közlekedési Kiadó, 2002, 17. o.
${ }^{4}$ Koszonits-Potocska-Pozsgai: Nemzetközi szállítmányozás, 2. köt. Magyar Közlekedési Kiadó, 2002, 36. o. és John F. Wilson: Carriage of Goods By Sea. Pearson Education Ltd., 2010, 4. o.

${ }^{5}$ Koszonits-Potocska-Pozsgai: Nemzetközi szállítmányozás, 2. köt. Magyar Közlekedési Kiadó, 2002, 35. o.

${ }^{6}$ Koszonits-Potocska-Pozsgai: Nemzetközi szállítmányozás, 2. köt. Magyar Közlekedési Kiadó, 2002, 36. o.

${ }^{7}$ John F. Wilson: Carriage of Goods By Sea. Pearson Education Ltd., 2010, 7-8. o.

${ }^{8}$ John F. Wilson: Carriage of Goods By Sea. Pearson Education Ltd., 2010, 68, 144. o.

${ }^{9}$ Stephen Mills: Bills of Lading - A guide to good practice. Anchorage Press, 1998, 60-61. o.

${ }^{10}$ E szereplőkről ld. az I. cikk Definíciók címü részt, az okirati feladóról továbbá a 33. cikket is.

${ }^{11}$ Ezt döntően a fuvarokmány típusa, a forgathatósága és a formája (papír vagy elektronikus) befolyásolja.

12 John F. Wilson: Carriage of Goods By Sea. Pearson Education Ltd., 2010, 115. o.

${ }^{13}$ Roy C. Cave - Herbert H. Coulson: A Source Book for Medieval Economic History. Biblo\&Tannen, New York, 1965, 159-160 o. A forrás egy 1248-ból származó hajóraklevél szövegét idézi.

${ }^{14}$ Ordonnance d'Anvers 1570. Ordonnance d'Amsterdam 1598. Ordonnance des villes Hanzéatiques, Lübeck 1591.

${ }^{15}$ John F. Wilson: Carriage of Goods By Sea. Pearson Education Ltd., 2010, 155. o.

${ }_{17}^{16}$ Stephen Mills: Bills of Lading - A guide to good practice. Anchorage Press, 1998, 31-32. o.

${ }^{17}$ John F. Wilson: Carriage of Goods By Sea. Pearson Education Ltd., 2010, 115. o.

${ }^{18}$ John F. Wilson: Carriage of Goods By Sea. Pearson Education Ltd., 2010, 115. o.

${ }^{19}$ Stephen Mills: Bills of Lading - A guide to good practice. Anchorage Press, 1998, 32. o.

${ }^{20}$ John F. Wilson: Carriage of Goods By Sea. Pearson Education Ltd., 2010, 116. o.

${ }^{21}$ Koszonits-Potocska-Pozsgai: Nemzetközi szállítmányozás, 2. köt. Magyar Közlekedési Kiadó, 2002, 17. o.

${ }^{22}$ John F. Wilson: Carriage of Goods By Sea. Pearson Education Ltd., 2010, 116. és 174. o.

${ }^{23}$ A Hágai Szabályzatnak volt később egy másik módosítása is. Ezt az új jegyzőkönyvet 1979. december 21én fogadták el, és a Hágai Szabályzat IV. cikk 5. pontját módosította a fuvarozói felelösség korlátozásával kapcsolatosan: a Nemzetközi Valutaalap SDR (special drawing right) nevü egységében fejezte ki a fuvarozó maximált felelösségét.

${ }^{24}$ John F. Wilson: Carriage of Goods By Sea. Pearson Education Ltd., 2010, 116-117. és 215. o.

${ }^{25}$ http://www.mcgill.ca/maritimelaw/glossaries/package-kilo/\#LL (2012. ápr. 30.)

${ }^{26}$ Carriage of Goods by Sea Act 1991. A törvény 2. része a módosított Hágai, 3. része pedig a Hamburgi Szabályzat alkalmazásáról rendelkezik.

${ }^{27}$ A folyamatról ld. részletesen a Rotterdami szabályzat honlapját: http://www.rotterdamrules2009.com/cms/ (2012. ápr. 30.)

${ }^{28}$ Carriage of Goods by Sea Act 1971, 1. szakasz (2) bekezdés

${ }^{29}$ Carriage of Goods by Sea Act 1924. E törvény hatályon kívül helyezésével a Hágai Szabályzat eredeti formájában már nem, csakis a Visby módosítások szerinti szöveggel alkalmazandó.

${ }^{30}$ Ilyen például a törvény 1. szakasz (6) bekezdése, mely pontosítja, mit kell érteni a Hágai/Visby Szabályzat X. cikk (c) pontjában szereplö „,bill of lading” kifejezés alatt.

${ }^{31}$ Ilyen például a törvény 1. szakasz (3) és (7) bekezdése. Az előbbi kiterjeszti a Hágai/Visby Szabályzat alkalmazását arra az esetre is, ha két, az Egyesült Királyságon belüli kikötő között kerül sor fuvarozásra, az utóbbi pedig a fedélzeti árukat és az élő állatokat vonja a Szabályzat hatálya alá.

${ }^{32}$ The Carriage of Goods by Sea Act. Eltérés van például a $\$ 1304$ (4) bekezdésben (kitérés szabályozása), az § 1309-1315 szakaszok kiegészítések (feladók közötti megkülönböztetés, ömlesztett áru stb.).

33 A Hágai Szabályzat cikkeinek számozása római számmal történik, a magyar törvény azonban arab számokat használ.

${ }^{34}$ International Commercial Terms (Nemzetközi Kereskedelmi Feltételek). A sztenderdeket elöször 1936-ban fogalmazták meg, legutóbbi módosítása az INCOTERMS 2010.

${ }^{35}$ Uniform Customs and Practice for Documentary Credit (Az okmányos meghitelezésre vonatkozó egységes szabályok és szokványok). Elöször 1933-ban foglalták össze, jelenleg a UCP 600 az aktuális, melynek 20. cikke a normál hajóraklevélre, 22. cikke a bérelt hajózás során kiállított hajóraklevélre tartalmaz szabályokat. 
${ }^{36}$ Ilyen például az elektronikus hajóraklevelekre vonatkozó szabályzat (Rules for electronic bills of lading).

${ }^{37}$ Stephen Mills: Bills of Lading - A guide to good practice. Anchorage Press, 1998, 42-43. o.

${ }^{38}$ I. cikk (b) pont: „«Fuvarozási szerződés» alatt csak azok a fuvarozási szerződések értendők, melyeket hajóraklevéllel vagy más hasonló tulajdonjogot megtestesítő okirattal tanúsítanak [...]”.

${ }^{39}$ Koszonits-Potocska-Pozsgai: Nemzetközi szállítmányozás, 2. köt. Magyar Közlekedési Kiadó, 2002, 25-

26. o., de e két típust szabályozzák a Carriage of Goods by Sea Act 1992, 1. szakasz 3-4. bekezdései is.

${ }^{40}$ Ezt támasztja alá a Hágai és a Hágai/Visby Szabályzat VI. cikke, a Hamburgi Szabályzat: 18. cikke is.

${ }^{41}$ Carriage of Goods by SeaA ct 1992, 1. szakasz 2. bekezdés. Az alaptípus így feltehetően a „shipped B/L”.

${ }^{42}$ Hágai és Hágai/Visby Sz. III. cikk 3. pont, Hamburgi Sz. 15. cikk 1-2. pont, Rotterdami Sz. 35-36. cikk

${ }^{43}$ Hágai és Hágai/Visby Sz. III. cikk 5. pont, Hamburgi Sz. 17. cikk 1. pont, Rotterdami Sz. 31. cikk

${ }^{44}$ Hágai és Hágai/Visby Sz. III. cikk 3. pont, Hamburgi Sz. 16. cikk 1. pont, Rotterdami Sz. 40. cikk

${ }^{45}$ Hágai és Hágai/Visby Sz. III. cikk 8. pont, Hamburgi Sz. 23. cikk 1. pont, Rotterdami Sz. 79. cikk 1. pont

${ }^{46}$ Hágai és Hágai/Visby Sz. III. cikk 4. pont, Hamburgi Sz. 16. cikk 3. (a) pont, Rotterdami Sz. 41. cikk (a) p.

${ }^{47}$ A Hágai Szabályzatban ez nem szerepel, a Hágai/Visby Sz. III. cikk módosított 4. pontjában már igen. Ugyanígy a Hamburgi Sz. 16. cikk 3. (b) pont, Rotterdami Sz.: 41. cikk (b) pont.

${ }^{48}$ Az Egyesült Királyságban, ahol meghatározó szerepe van az esetjognak, az árutulajdonságok nem mindegyikénél érvényesült egyformán ez a szabály. Erről ld. részletesen John F. Wilson: Carriage of Goods By Sea. Pearson Education Ltd., 2010, 118-129. o.

${ }^{49} \mathrm{Az}$ angol esetjogban van olyan álláspont, mely szerint a hajóraklevél a fuvarozási szerződés írásba foglalása, ezáltal a szóban kötött szerződés többé már nem lesz módosítható. Ld.: Leduc v Ward ügy.

${ }^{50}$ Bár Stephen Mills könyvében (Bills of Lading - A guide to good practice. Anchorage Press, 1998) elöször egynek tekinti a hajóraklevelet és a fuvarozási szerződést (31. o.), később ezt korrigálja (66. o.), végül pedig már a fuvarozási szerződéstől megkülönböztetendő külön hajóraklevél-szerződés létezéséről beszél (71. o.).

${ }^{51}$ Erről ld. részletesen John F. Wilson: Carriage of Goods By Sea. Pearson Education Ltd., 2010, 129-132. o.

${ }^{52}$ Bár a Hágai és a Hágai/Visby Szabályzatban ez nem szerepel, a Hamburgi Szabályzat 16. cikk 4. pontja a fuvardíjra és a hajóálláspénzre, a Rotterdami Szabályzat 41. cikke pedig általánosan kimondja ezt. Az Egyesült Királyság joga is ennek megfelelően szabályozza a kérdést, ld: részletesen John F. Wilson: Carriage of Goods By Sea. Pearson Education Ltd., 2010, 129-132. o.

${ }^{53}$ A Polgári Törvénykönyvröl szóló 1959 . évi IV. törvény 489. § (1) bekezdése

${ }^{54}$ Harsányi Gyöngyi: Magyar értékpapírjog. Novotni Kiadó, Miskolc, 2000, 15. o. Szécsényi László: Értékpapírjog. Dialóg Campus, 2002, 53. és 58. o. Az Amerikai Egyesült Államok esetében is a Uniform Commercial Code (UCC) 7. §-a együtt szabályozza a hajóraklevelet a közraktári jeggyel (warehouse receipt).

${ }^{55}$ John F. Wilson: Carriage of Goods By Sea. Pearson Education Ltd., 2010, 133-142. o.

${ }^{56}$ Stephen Mills: Bills of Lading - A guide to good practice. Anchorage Press, 1998, 70. o.

${ }^{57}$ John F. Wilson: Carriage of Goods By Sea. Pearson Education Ltd., 2010, 132., 161-163. o.

${ }^{58}$ Van olyan álláspont is az angol jogi gondolkodásban, ami szerint a névre szóló hajóraklevél a Hágai/Visby Szabályzat I. cikk (b) pontbeli ,any similar document of title” fogalma alá tartozhat. Ld. később kifejtve.

${ }^{59}$ John F. Wilson: Carriage of Goods By Sea. Pearson Education Ltd., 2010, 133. o.

${ }^{60}$ John F. Wilson: Carriage of Goods By Sea. Pearson Education Ltd., 2010, 117-118. o.

${ }^{61}$ Koszonits-Potocska-Pozsgai: Nemzetközi szállítmányozás, 2. köt. Magyar Közlekedési Kiadó, 2002, 26. o.

${ }^{62}$ Stephen Mills: Bills of Lading - A guide to good practice. Anchorage Press, 1998, 60-62. o.

${ }^{63}$ Stephen Mills: Bills of Lading - A guide to good practice. Anchorage Press, 1998, 15-17., 45-47. o.

${ }^{64}$ Stephen Mills: Bills of Lading - A guide to good practice. Anchorage Press, 1998, 45-48. o.

${ }^{65}$ Stephen Mills: Bills of Lading - A guide to good practice. Anchorage Press, 1998, 59. o.

${ }^{66}$ Stephen Mills: Bills of Lading - A guide to good practice. Anchorage Press, 1998, 48-49. o.

${ }^{67}$ Koszonits-Potocska-Pozsgai: Nemzetközi szállítmányozás, 2. köt. Magyar Közlekedési Kiadó, 2002, 23. o.

${ }^{68}$ Például az USA szövetségi hajóraklevél törvényének (Federal Bill of Lading Act) 80112. § (a) pontja.

${ }^{69}$ John F. Wilson: Carriage of Goods By Sea. Pearson Education Ltd., 2010, 133, 154. o.

${ }^{70}$ Stephen Mills: Bills of Lading - A guide to good practice. Anchorage Press, 1998, 72-73. o.

${ }_{71}^{71}$ Stephen Mills: Bills of Lading - A guide to good practice. Anchorage Press, 1998, 49. o.

${ }^{72}$ John F. Wilson: Carriage of Goods By Sea. Pearson Education Ltd., 2010, 172-173. o.

${ }^{73}$ Ld.: http://www.aclcargo.com/billofLading.php\# (2012. ápr. 30.)

${ }_{75}^{74}$ A cikk négy pontba csoportosítva sorolja fel a tartalmi elemeket.

75 „Contract particulars” néven ez a fogalom a fuvarozási szerződéssel kapcsolatos bármilyen információt, még az aláírást is magába foglalja, ld.: 1. cikk 23. pont.

${ }^{76}$ John F. Wilson: Carriage of Goods By Sea. Pearson Education Ltd., 2010, 122. o.

${ }_{77}^{77}$ Stephen Mills: Bills of Lading - A guide to good practice. Anchorage Press, 1998, 52-53. o.

${ }^{78}$ John F. Wilson: Carriage of Goods By Sea. Pearson Education Ltd., 2010, 123. o.

${ }^{79}$ Stephen Mills: Bills of Lading - A guide to good practice. Anchorage Press, 1998, 53. o. 
${ }^{80}$ Stephen Mills: Bills of Lading - A guide to good practice. Anchorage Press, 1998, 55. o.

${ }^{81}$ Stephen Mills: Bills of Lading - A guide to good practice. Anchorage Press, 1998, 55-57. o.

${ }^{82}$ Hágai és Hágai/Visby Sz. III. cikk 5. pont, Hamburgi Sz. 17. cikk 1. pont, Rotterdami Sz. 31. cikk 2. pont

${ }^{83}$ Ld. ezzel kapcsolatban a Sea Success Maritime v African Maritime Carriers ügyet. Megtalálható: John F. Wilson: Carriage of Goods By Sea. Pearson Education Ltd., 2010, 123-124. o.

${ }^{84}$ Stephen Mills: Bills of Lading - A guide to good practice. Anchorage Press, 1998, 53. o.

${ }^{85}$ Hágai és Hágai/Visby Sz. III. cikk 3. pont, Hamburgi Sz. 15. cikk 1. pont, Rotterdami Sz. 36. cikk 1. pont

${ }^{86}$ Parsons v New Zealand Shipping Co

${ }^{87}$ The Saudi Crown ügy, John F. Wilson: Carriage of Goods By Sea. Pearson Education Ltd., 2010, 129. o.

${ }^{88}$ Stephen Mills: Bills of Lading - A guide to good practice. Anchorage Press, 1998, 53-54. o.

${ }^{89}$ Hágai és Hágai/Visby Sz. III. cikk 3. pont, Hamburgi Sz. 16. cikk 1. pont, Rotterdami Sz. 40. cikk

${ }^{90}$ Stephen Mills: Bills of Lading - A guide to good practice. Anchorage Press, 1998, 51-54. o.

${ }^{91}$ Hágai és Hágai/Visby Sz. III. cikk 8. pont, Hamburgi Sz. 23. cikk 1. pont, Rotterdami Sz. 79. cikk 1. pont

92 John F. Wilson: Carriage of Goods By Sea. Pearson Education Ltd., 2010, 158-159. o.

${ }^{93}$ Ld. erröl részletesen a Maritime knowhow honlapját: http://www.maritimeknowhow.com/English/KnowHow/Bill_of_Lading/types_of_bill_of_lading/long_form_bill_of_lading.html (2012. ápr. 30.).

${ }^{94}$ Koszonits-Potocska-Pozsgai: Nemzetközi szállítmányozás, 2 . köt. Magyar Közlekedési Kiadó, 2002, 25 . o

${ }^{95}$ Stephen Mills: Bills of Lading - A guide to good practice. Anchorage Press, 1998, 55. o.

${ }^{96}$ Koszonits-Potocska-Pozsgai: Nemzetközi szállítmányozás, 2. köt. Magyar Közlekedési Kiadó, 2002, 24. o

${ }^{97}$ Hágai és Hágai/Visby Sz. III. cikk 7. pont, Hamburgi Sz. 15. cikk 2. pont

${ }^{98}$ Koszonits-Potocska-Pozsgai: Nemzetközi szállítmányozás, 2. köt. Magyar Közlekedési Kiadó, 2002, 25. o

${ }^{99}$ John F. Wilson: Carriage of Goods By Sea. Pearson Education Ltd., 2010, 6. o.

${ }^{100}$ Koszonits-Potocska-Pozsgai: Nemzetközi szállítmányozás, 2. köt. Magyar Közlekedési Kiadó, 2002, 25. o

${ }^{101}$ John F. Wilson: Carriage of Goods By Sea. Pearson Education Ltd., 2010, 253. o.

${ }^{102}$ Koszonits-Potocska-Pozsgai: Nemzetközi szállítmányozás, 2. köt. Magyar Közlekedési Kiadó, 2002, 25. o

${ }^{103}$ Stephen Mills: Bills of Lading - A guide to good practice. Anchorage Press, 1998, 86-87. o.

${ }^{104}$ Poysl Dóra: Az import irányú konténeres tengeri fuvarozás során felmerülő problémák, az ezekre irányuló megoldási javaslatok a Cargomind Kft. gyakorlatában. Budapesti Gazdasági Főiskola, 2009, 32-33. o.

${ }^{105}$ Ennek alternatív megoldása a fuvarozótól a fő hajóraklevél átadása ellenében kapott kiszolgáltatási jegyek alkalmazása, melyek révén a gyüjtőszállítmányból minden címzett a maga rakományrészét veheti át, ez esetben azonban nem a szállítmányozótól, hanem a fuvarozótól. Ld.: Koszonits-Potocska-Pozsgai: Nemzetközi szállítmányozás, 2. köt. Magyar Közlekedési Kiadó, 2002, 25. o.

${ }^{106}$ Stephen Mills: Bills of Lading - A guide to good practice. Anchorage Press, 1998, 86-87. o.

${ }^{107}$ Carriage of Goods by Sea Act 1991 4. szakasz (2) bekezdése értelmében a nem átruházható dokumentum fogalom a tengeri fuvarlevelet (sea waybill) jelenti.

${ }^{108}$ Az Amerikai Egyesült Államok esetében a Uniform Commercial Code (UCC) 7. §-a.

${ }^{109}$ Bills of Lading Act (Loi sur les connaissements) 1985 1-4. szakaszai

${ }^{110}$ John F. Wilson: Carriage of Goods By Sea. Pearson Education Ltd., 2010, 133-135. o.

${ }^{111}$ A „nemo plus iuris” elve alól a polgári törvénykönyv 119. §-a fogalmaz meg kivételt: „Akire pénzt vagy bemutatóra szóló értékpapírt ruháznak át, tulajdonossá lesz akkor is, ha az átruházó nem volt tulajdonos”.

${ }_{112}^{112}$ Stephen Mills: Bills of Lading - A guide to good practice. Anchorage Press, 1998, 64-65. o.

${ }^{113}$ Stephen Mills: Bills of Lading - A guide to good practice. Anchorage Press, 1998, 87. o.

${ }^{114}$ Például az Egyesült Királyság 1992-es tengeri árufuvarozási törvénye 1. szakasz (2) bekezdése, valamint 5. szakasz (2) bekezdés (b) pontja.

${ }^{115}$ A forgatás feltétele rendszerint az értékpapír szövegében szereplő kifejezett feljogosítás, úgynevezett pozitív rendeleti záradék. Ezért nevezik ezeket rendeletre szóló értékpapírnak (order bill).

${ }^{116}$ Koszonits-Potocska-Pozsgai: Nemzetközi szállítmányozás, 2. köt. Magyar Közlekedési Kiadó, 2002, 24. o

${ }^{117}$ Stephen Mills: Bills of Lading - A guide to good practice. Anchorage Press, 1998, 65. o.

${ }^{118} \mathrm{Az}$ angliai Barber v Meyerstein esetben kimondták, hogy az áru tulajdonjoga az első ellenérték fejében szerző vevőre száll át.

119 John F. Wilson: Carriage of Goods By Sea. Pearson Education Ltd., 2010, 154. o.

${ }^{120}$ Stephen Mills: Bills of Lading - A guide to good practice. Anchorage Press, 1998, 71-72. o.

${ }^{121}$ Ld. ezzel kapcsolatban a Sze Hai Tong Bank Ltd v Rambler Cycle Co Ltd esetet.

122 John F. Wilson: Carriage of Goods By Sea. Pearson Education Ltd., 2010, 155. o.

${ }^{123}$ Ld. ezzel kapcsolatban a Glyn Mills v East \& West India Dock Co esetet.

${ }^{124}$ Stephen Mills: Bills of Lading - A guide to good practice. Anchorage Press, 1998, 73-74. o.

${ }^{125}$ Stephen Mills: Bills of Lading - A guide to good practice. Anchorage Press, 1998, 72. o.

${ }^{126}$ John F. Wilson: Carriage of Goods By Sea. Pearson Education Ltd., 2010, 157. o. 
${ }^{127}$ Így például a Maersk Line általános rendeletre szóló hajóraklevél esetén a feladó, bank rendeletére szóló hajóraklevél esetén a bank általi forgatást vár el, mindkét esetben azonban a címzettnek az aláírását is megköveteli, amivel az átvételt igazolja.

${ }^{128}$ Hágai és Hágai/Visby Sz. I. cikk (b) pont, Hamburgi Sz. 2. cikk 3. pont, Rotterdami Sz. 6-7. cikk

${ }^{129}$ John F. Wilson: Carriage of Goods By Sea. Pearson Education Ltd., 2010, 6-7., 244-251. o.

${ }^{130}$ Stephen Mills: Bills of Lading - A guide to good practice. Anchorage Press, 1998, 76-77. o.

131 John F. Wilson: Carriage of Goods By Sea. Pearson Education Ltd., 2010, 6-7., 247. o.

${ }^{132}$ Stephen Mills: Bills of Lading - A guide to good practice. Anchorage Press, 1998, 46-49., 56 o.

133 John F. Wilson: Carriage of Goods By Sea. Pearson Education Ltd., 2010, 163-165. o.

${ }^{134}$ John F. Wilson: Carriage of Goods By Sea. Pearson Education Ltd., 2010, 166. o.

${ }^{135}$ Spiczmüller Bencze: A tengeri hajóraklevél dematerializálódásának problematikája a polgári - és az elektronikus - kereskedelmi jogban. Ld.: http://www.jogiforum.hu/publikaciok/425 (2012. ápr. 30.)

${ }_{136}$ Ld.: http://www.comitemaritime.org/Rules-for-Electronic-Bills-of-Lading/0,2728,12832,00.html (2012. ápr. 30.)

${ }^{37}$ John F. Wilson: Carriage of Goods By Sea. Pearson Education Ltd., 2010, 165-171. o. 